\title{
The Smicridea (Smicridea) fasciatella species group (Trichoptera: Hydropsychidae) in Brazil: six new species and new distributional records
}

\author{
Gleison Robson DESIDERIO ${ }^{\circledR 1, *}$, Ana Maria PES ${ }^{\circledR 2}$, \\ Vanderly ANDRADE-SOUZA ${ }^{\circledR 3}$ \& Neusa HAMADA ${ }^{\circledR 4}$ \\ 1,2,3,4 Instituto Nacional de Pesquisas da Amazônia (INPA), Coordenação de Pós-Graduação (COPOG), \\ Divisão do Curso em Entomologia (DiEnt), Coordenação de Biodiversidade (CoBio), Manaus, \\ Amazonas, Brazil. \\ *Correspondence author: gleysonbio@gmail.com \\ ${ }^{2}$ Email: anampes@gmail.com \\ ${ }^{3}$ Email: vanderlyasouza@gmail.com \\ ${ }^{4}$ Email: neusaha@gmail.com \\ ${ }^{1}$ urn:1sid:zoobank.org:author:C1D0E728-8313-4981-9C9A-0BC3BB8742DB
${ }^{2}$ urn:1sid:zoobank.org:author:03D29AFD-A7EE-49DA-9740-7FA0F34932AF
${ }^{3}$ urn:1sid:zoobank.org:author:4428B020-7CE1-40C4-98A4-A9C6DD783286
${ }^{4}$ urn:lsid:zoobank.org:author:0D02F36C-6B09-423C-95A6-6179E9808CD5
}

\begin{abstract}
The Smicridea (Smicridea) fasciatella species group occurs from the southwestern USA, throughout Central America, the Greater Antilles islands, and most of South America, except for the Chilean subregion. It is characterized by the phallic apparatus being a simple tube with eversible internal sclerites at the apex. The fasciatella group is composed of 61 species, of which only 11 occur in Brazil, mainly in the Atlantic Forest biome in the southeastern region. In order to reduce the Linnean and Wallacean shortfalls for the Smicridea Brazilian fauna, we diagnose, describe, and illustrate males of six new species in the fasciatella group: Smicridea (Smicridea) blahniki Desiderio, Pes \& Hamada sp. nov., S. (Smicridea) brevitruncata Desiderio, Pes \& Hamada sp. nov., S. (Smicridea) caaguara Desiderio, Pes \& Hamada sp. nov., S. (Smicridea) ipiranga Desiderio, Pes \& Hamada sp. nov., S. (Smicridea) jeaneae Desiderio, Pes \& Hamada sp. nov., and S. (Smicridea) polyacantha Desiderio, Pes \& Hamada sp. nov. Additionally, we provide distributional data for S. (Smicridea) albosignata Ulmer, 1907, S. (Smicridea) bivittata (Hagen, 1861), S. (Smicridea) erecta Flint, 1974, S. (Smicridea) obliqua Flint, 1974, S. (Smicridea) paranensis Flint, 1983, and S. (Smicridea) sattleri Denning \& Sykora, 1968. The number of S. (Smicridea) species in Brazil increases from 21 to 27 and Smicridea is recorded from the states of Acre, Amapá, and Sergipe for the first time.
\end{abstract}

Keywords. Aquatic insects, caddisfly, Smicrideinae, morphology, taxonomy.

Desiderio G.D., Pes A.M., Andrade-Souza V. \& Hamada N. 2021. The Smicridea (Smicridea) fasciatella species group (Trichoptera: Hydropsychidae) in Brazil: six new species and new distributional records. European Journal of Taxonomy 750: 156-196. https://doi.org/10.5852/ejt.2021.750.1371 


\section{Introduction}

Smicridea McLachlan, 1871 was established by McLachlan (1871) to include three species: Smicridea fasciatella McLachlan, 1871 from USA, Smicridea saucia McLachlan, 1871 from Peru, and Smicridea murina McLachlan, 1871 from Chile. It is the only genus of Smicrideinae Flint, 1974 (Hydropsychidae Curtis, 1835) occurring in the Western Hemisphere and the most diverse and abundant genus in this subfamily, with 245 species distributed from the southwestern USA to southern Argentina (Holzenthal \& Calor 2017; Alves et al. 2018; Mey \& Ospina-Torres 2018; Sganga \& Gibon 2018; Gibon \& Sganga 2019; Rázuri-Gonzales \& Armitage 2019; Vilarino et al. 2019; Desiderio et al. 2020).

Currently, Smicridea is divided into two subgenera: S. (Smicridea) McLachlan, 1871 (139 species) and S. (Rhyacophylax) Müller, 1879 (106 species). The subgenera can be distinguished in the adult stage by the wing venation, the male tibial spur formula, and the presence/absence of two pairs of internal reticulate sacs in segments VI and VII (Flint 1974a, 1989). Larval characters to distinguish subgenera are fewer and/or imprecise (Flint 1974a; Wiggins 1996; Sganga \& Fontanarrosa 2006).

According to Flint (1974a, 1989), the subgenus Smicridea is composed of five species groups: Smicridea annulicornis (7 species), Smicridea frequens (5 species), Smicridea smilodon (3 species), Smicridea fasciatella (61 species), and Smicridea nigripennis (60 species). The first three of these groups occur from southern Argentina to Chile (the Chilean subregion, as defined by Flint (1983)) and the remaining two groups occur from the southwestern USA, throughout Central America, the Antilles, and most of South America, except for the Chilean subregion (Flint 1974a, 1974b, 1983, 1989; Desiderio et al. 2020). Additionally, the endemic species S. complicatissima Flint, 1989 and S. matancilla Flint, 1989 from the Chilean region remain incertae sedis with respect to their assignment to species groups within the subgenus Smicridea (Flint 1989).

The species groups in this subgenus are circumscribed mainly on the basis of the characters of the male genitalia. The fasciatella group is characterized by a tubular phallus with eversible internal sclerites at the apex. Within the fasciatella group, Blahnik (1995) proposed the fasciatella complex, characterized by highly similar genitalia and significant differences in the color of the wings and body, and Flint (1981) recognized the albosignata complex, which is distinguished by having paired apicodorsal sclerites on the phallus. The fasciatella complex includes six species, S. astarte Malicky, 1980, S. catherinae Blahnik, 1995, S. fasciatella, S. hybrida Blahnik, 1995, S. lacanha Bueno-Soria \& Hamilton, 1986, and S. varia (Banks, 1913), and the albosignata complex has four species, S. albosignata Ulmer, 1907, S. bulbosa Flint, 1974, S. riita Flint, 1981, and S. meridensis Botosaneanu \& Flint, 1982.

In Brazil, Smicridea is the most diverse caddisfly genus with 62 recorded species; 21 of them are assigned to the subgenus Smicridea, of which 11 belong to the fasciatella group: S. aequalis Banks, 1920, S. albosignata Ulmer, 1907, S. bivittata (Hagen, 1861), S. capao Vilarino, Dias \& Calor, 2019, S. erecta Flint, 1974, S. gemina Blahnik, 1995, S. obliqua Flint, 1974, S. paranensis Flint, 1983, S. sattleri Denning \& Sykora, 1968, S. sepala Rocha, Dumas \& Nessimian, 2016, and S. truncata Flint, 1974 (Pes \& Santos 2020). Most of these species are concentrated in the Atlantic Forest biome in southeastern Brazil.

The aims of this study are to advance knowledge of caddisfly diversity, reducing the Linnean (Brown \& Lomolino 1998) and Wallacean (Lomolino 2004) shortfalls for Smicridea, and to describe and illustrate the males of six new species in the $S$. fasciatella group in Brazil. Additionally, we provide new distributional records for S. albosignata, S. bivittata, S. erecta, S. obliqua, S. paranensis, and S. sattleri. 


\section{Material and methods}

\section{Specimen collection, preparation, and observation}

Adults were collected with Pennsylvania traps (Frost 1957), UV light pan traps (Calor \& Mariano 2012), a white sheet with an LED light, and Malaise traps (Gressitt \& Gressitt 1962), or manually with an entomological net. Most of the collected specimens were preserved in $80 \%$ or $96 \%$ ethanol, while the specimens collected on the white sheets were pinned and preserved dried.

To observe male genital structures, the abdomen of each specimen was removed and cleared using hot 10\% $\mathrm{KOH}$ as detailed by Blahnik \& Holzenthal (2004); sometimes $85 \%$ lactic acid was also used following procedures detailed by Blahnik et al. (2007) in order to evert the endothecal spines of the phallus. After clearing, the abdomen was mounted on a temporary slide using glycerin and examined under a Leica DM5500 B compound microscope. After examination, it was stored in a microvial filled with glycerin, together with the remains of the respective specimen in a plastic vial with $80 \%$ ethanol.

\section{Illustrations and maps}

Photographs of the habitus, head, and forewings were obtained with a Leica DMC4500 digital video camera attached to a Leica M205A stereo microscope or a Leica DFC420 digital video camera attached to a Leica M165C stereo microscope, both using an LED illumination dome (Kawada \& Buffington 2016). Stacks of images of each structure were produced at different focal distances; these were then automatically combined into a single image with a greater depth of field using the Helicon Focus ${ }^{\circledR}$ stacking software (ver. 7.6.4 Pro).

Male genitalia were photographed using a Leica DFC295 video camera attached to a Leica DM5500 B compound microscope, and the stacked images were used as templates to create vector graphic illustrations in Adobe Illustrator ${ }^{\circledR}$. Photographs were assembled into plates using Adobe Photoshop ${ }^{\circledR}$.

The distribution maps were prepared using QGIS Las Palmas ver. 2.18.10 software (QGIS Development Team 2016). Vector and raster maps used IBGE (2019) and Natural Earth (2020) data. Distribution data for species of Smicridea were compiled from the literature, analyzed specimens, and collection datasets included in the Global Biodiversity Information Facility (GBIF 2020).

\section{Morphological terminology, descriptions, and material examined}

Morphological terminology follows mostly Blahnik (1995) for the male genitalia and Wells \& Neboiss (2018) for the head setal warts.

Species descriptions were made using the DELTA (Description Language for Taxonomy) software (Dallwitz et al. 1999) to promote consistency and standardization in descriptive taxonomy. The style of descriptions follows Desiderio et al. (2020).

Lists of material examined were prepared using the AUTOMATEX macro in Microsoft Excel (Brown 2013).
Abbreviations of genital structures
al. wt. = anterolateral wart
am. wt. = anteromesal wart
apm. lb. = apicomesal lobe
as. ia. = apical segment of the inferior appendage
bs. ia. = basal segment of the inferior appendage
dl. pl. $=$ dorsolateral plates on the phallic apparatus 


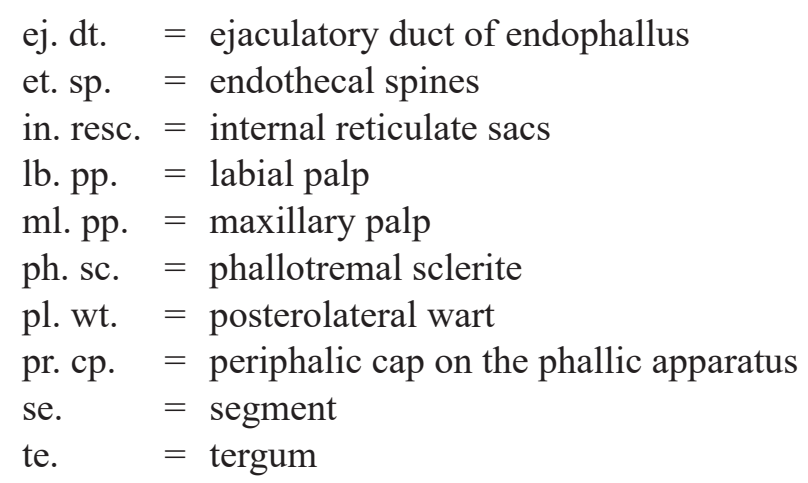

\section{Repositories}

Types and other material examined are deposited in the following collections:

CZMA = Coleção Zoológica do Maranhão, Centro de Estudos Superiores de Caxias, Universidade Estadual do Maranhão, Caxias, Brazil

DZRJ = Coleção Entomológica Prof. José Alfredo Pinheiro Dutra, Departamento de Zoologia, Universidade Federal do Rio de Janeiro, Rio de Janeiro, Brazil

DZUP = Coleção Entomológica Padre Jesus Santiago Moure, Departamento de Zoologia, Universidade Federal do Paraná, Curitiba, Brazil

INPA = Coleção de Invertebrados, Instituto Nacional de Pesquisas da Amazônia, Manaus, Brazil

MZUSP $=$ Museu de Zoologia da Universidade de São Paulo, São Paulo, Brazil

UFBA $=$ Museu de Zoologia da Universidade Federal da Bahia, Salvador, Brazil

\section{Results}

Class Insecta Linnaeus, 1758

Order Trichoptera Kirby, 1813

Suborder Annulipalpia Martynov, 1924

Superfamily Hydropsychoidea Curtis, 1835

Family Hydropsychidae Curtis, 1835

Subfamily Smicrideinae Flint, 1974

Genus Smicridea McLachlan, 1871

Smicridea (Smicridea) blahniki Desiderio, Pes \& Hamada sp. nov. urn:1sid:zoobank.org:act:FD50773D-473C-4AC6-979F-D3F9E3B410E0

Figs $1-3,4 \mathrm{~A}$

\section{Diagnosis}

Smicridea blahniki sp. nov. is similar to $S$. erecta and S. jeaneae Desiderio, Pes \& Hamada sp. nov. based on the strong, pointed apicomesal lobes on tergum X. Of these species, the new species is most similar to $S$. erecta, because the apicomesal lobes in both species touch distally and each lobe bears one pair of short, thin apical setae in dorsal view, while in S. jeaneae sp. nov., the apicomesal lobes do not touch distally and each has three medium-sized, thin apical setae. Smicridea blahniki sp. nov. has one pair of long, stout subapical setae on the apicomesal lobe of tergum X, whereas $S$. erecta has one pair of mediumsized, thin setae (absent in $S$. jeaneae sp. nov.). The basal segment of the inferior appendage in the new species has five stout apical spine-like setae, one long seta on the dorsal surface and four medium-sized on the mesal margin, whereas $S$. erecta and $S$. jeaneae sp. nov. have three stout apical spine-like setae (one dorsal and two on the internal margin). Additionally, the apical segment of the inferior appendage 
in S. blahniki sp. nov. is thick, slightly curved medially, and has a rounded apex, while in S. erecta and $S$. jeaneae sp. nov., this segment is slender, strongly curved medially, and has a slightly acute apex. Furthermore, S. blahniki sp. nov. can be recognized by the stethoscope-shaped phallotremal sclerite of the phallic apparatus in dorsal view, while in $S$. erecta this sclerite is ribbon-shaped and in $S$. jeaneae sp. nov. it is U-shaped in the proximal region and hastate in the distal region.

\section{Etymology}

The specific epithet is in honor of Dr Roger J. Blahnik (University of Minnesota, USA) in recognition of his contributions to the taxonomy and systematics of Neotropical caddisflies.

\section{Material examined}

\section{Holotype}

BRAZIL - ${ }^{\lambda}$; Amazonas, Barcelos, Parque Estadual Serra do Aracá, $1^{\text {st }}$ order stream; 00 $54^{\prime} 13.68^{\prime \prime}$ N, 6326'01.18" W; 1112 m a.s.1.; 2 Aug. 2009; A.M.P. Santos, N. Ferreira Jr and F.F. Salles leg.; Malaise trap; INPA-TRI 000106.

\section{Paratype}

BRAZIL $・ 1$; ; same collection data as for holotype; INPA-TRI 000107.

\section{Description}

Adult male (Figs 1-2)

FoREWING LENGTH. 4.15, $4.67 \mathrm{~mm}(\mathrm{n}=2)$.

CoLOR. General color brown (in alcohol) (Fig. 1A). Antennae yellowish brown (Fig. 1A). Head brown, denuded (Fig. 1B-C); dorsally with weakly-pronounced median suture; with five setal warts; anteromesal wart small, rounded; anterolateral pair undivided, weakly delimited; posterolateral pair large, ovoid (Fig. 1C). Maxillary palp with segments $1-4$ increasing gradually about $0.8 \times$ in size toward more apical segments, segment 5 long, about $1.2 \times$ as long as all previous segments combined (Fig. 1B). Thorax pale brown, without setae (old specimens); legs brown, with mid leg tarsi yellowish (Fig. 1A). Wing venation typical for subgenus (Fig. 1D-E). Forewings, in alcohol, uniformly brown, with small white spot on apex of $\mathrm{Cu} 2$ (Fig. 1D). Sternum $\mathrm{V}$ with anterolateral glandular processes as long as sternum. Abdominal segments VI and VII with 2 pairs of internal glands, both pairs longer than their containing segments (Fig. 1F).

Male genitalia (Fig. 2). Segment IX in lateral view with anterolateral margin nearly straight, strongly sclerotized (Fig. 2A); posterodorsal margin bearing small spicules, distributed in a subtriangular band (Fig. 2B). Tergum X elongate; in lateral view, ventrolateral margin strongly sclerotized, with four mediumsized, thin setae on apical third; apex with sharp notch, ending in slender, straight lobe (Fig. 2A); in dorsal view, lateral margin rounded; dorsomesal setose area bearing three medium-sized, thin setae; divided apicomesally by V-shaped incision about $1 / 4$ its length; apex of tergite rounded, with strong, pointed apicomesal lobe, touching distally, each bearing one pair of long, stout subapical setae and one pair of short, thin apical setae (Fig. 2B). Inferior appendages 2-segmented; basal segment long, slightly inflated distally, covered with long, thin setae, with a group of stout apical spine-like setae, one long seta dorsally and four medium-sized setae on mesal margin; apical segment short, about $1 / 3$ as long as basal segment, thick, slightly curved medially, apex rounded with numerous short, thin setae on mesal margin (Fig. 2B). Phallic apparatus long and tubular; basal section, in lateral view, enlarged, $4 \times$ diameter of phallotheca at its narrowest point, forming an angle of about $93^{\circ}$ with apical section; median section of phallotheca straight, with dorsal periphalic cap sclerotized, slender, and upturned (Fig. 2C); apex enlarged, without processes or plates; endothecal membranes without spines; phallotremal sclerite, in dorsal view, distinct, strongly sclerotized, stethoscope-shaped, proximal region slightly bifid and distal region with acute arms 

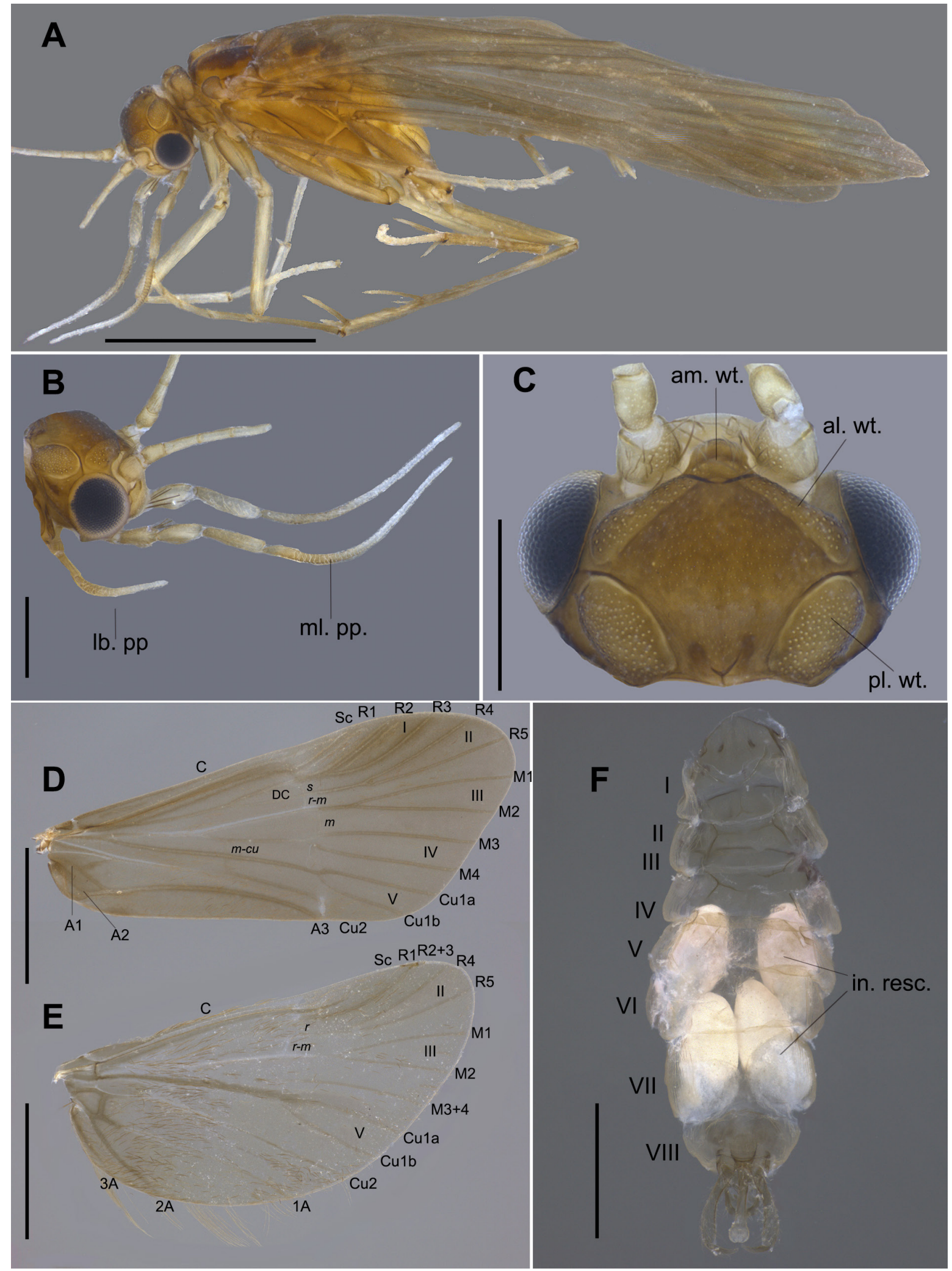

Fig. 1. Smicridea (Smicridea) blahniki Desiderio, Pes \& Hamada sp. nov., holotype, ふ̋ (INPA-TRI 000106). A. Lateral habitus (in alcohol). B. Head, right lateral view. C. Head, dorsal view. D. Forewing, right dorsal view. E. Hind wing, right dorsal view. F. Abdomen, ventral view. Scale bars in $\mathrm{mm}: \mathrm{A}=2 ; \mathrm{B}-\mathrm{C}=$ $0.5 ; \mathrm{D}-\mathrm{F}=1$. 
(Fig. 2D-E); in lateral view, slender, with dark brown comma-like median depression, distally arched, directed posterad (Fig. 2C). Ejaculatory duct of endophallus, in lateral view, distinct, sclerotized (Fig. 2C).
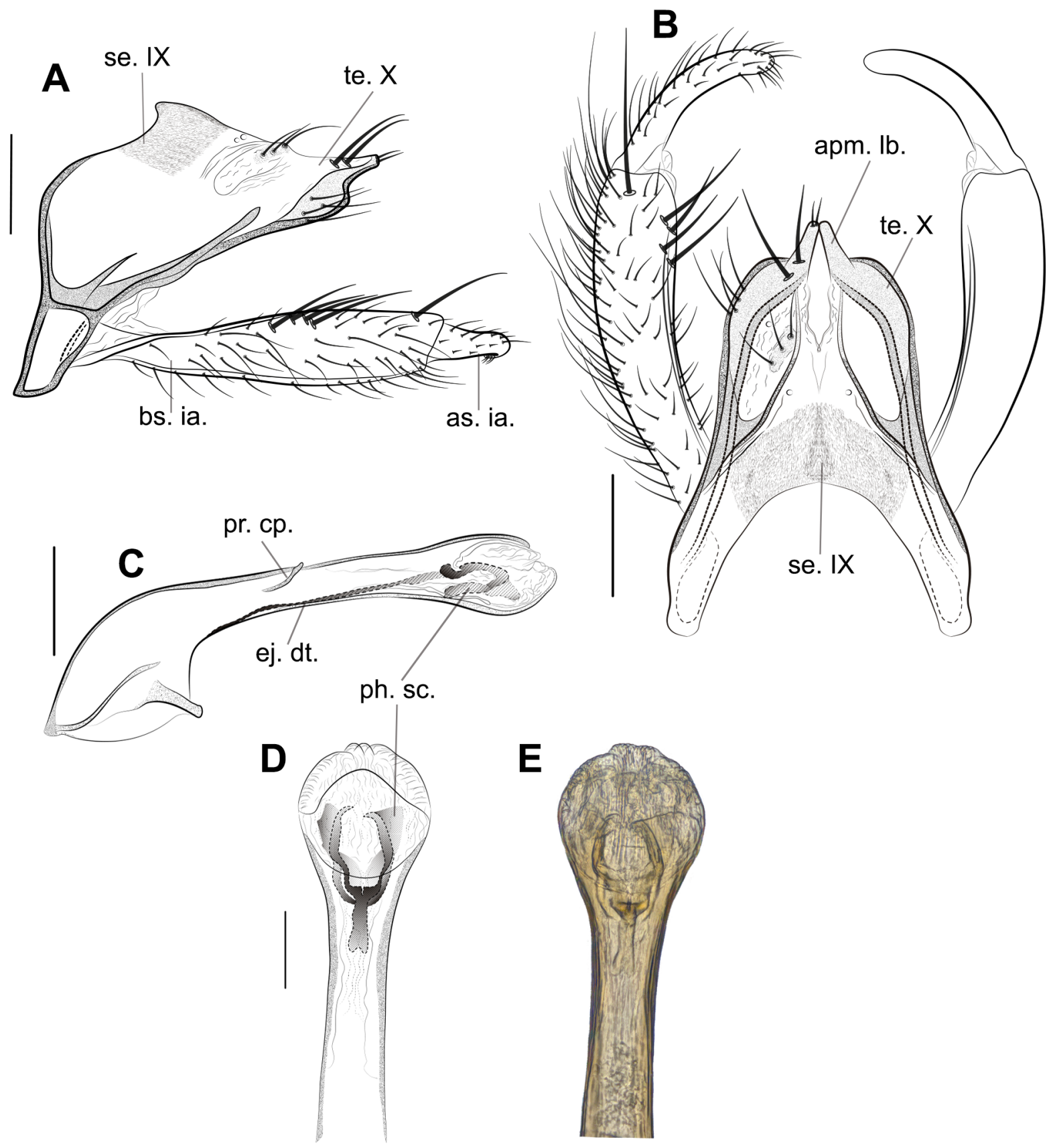

Fig. 2. Smicridea (Smicridea) blahniki Desiderio, Pes \& Hamada sp. nov., male terminalia, holotype (INPA-TRI 000106). A. Terga IX, $X$ and inferior appendages, lateral view. B. Same, dorsal view. C. Phallic apparatus, lateral view. D. Apex of phallic apparatus, dorsal view. E. Apex of phallic apparatus (photograph). Scale bars in mm: A-C $=0.1 ; \mathrm{D}-\mathrm{E}=0.05$. 


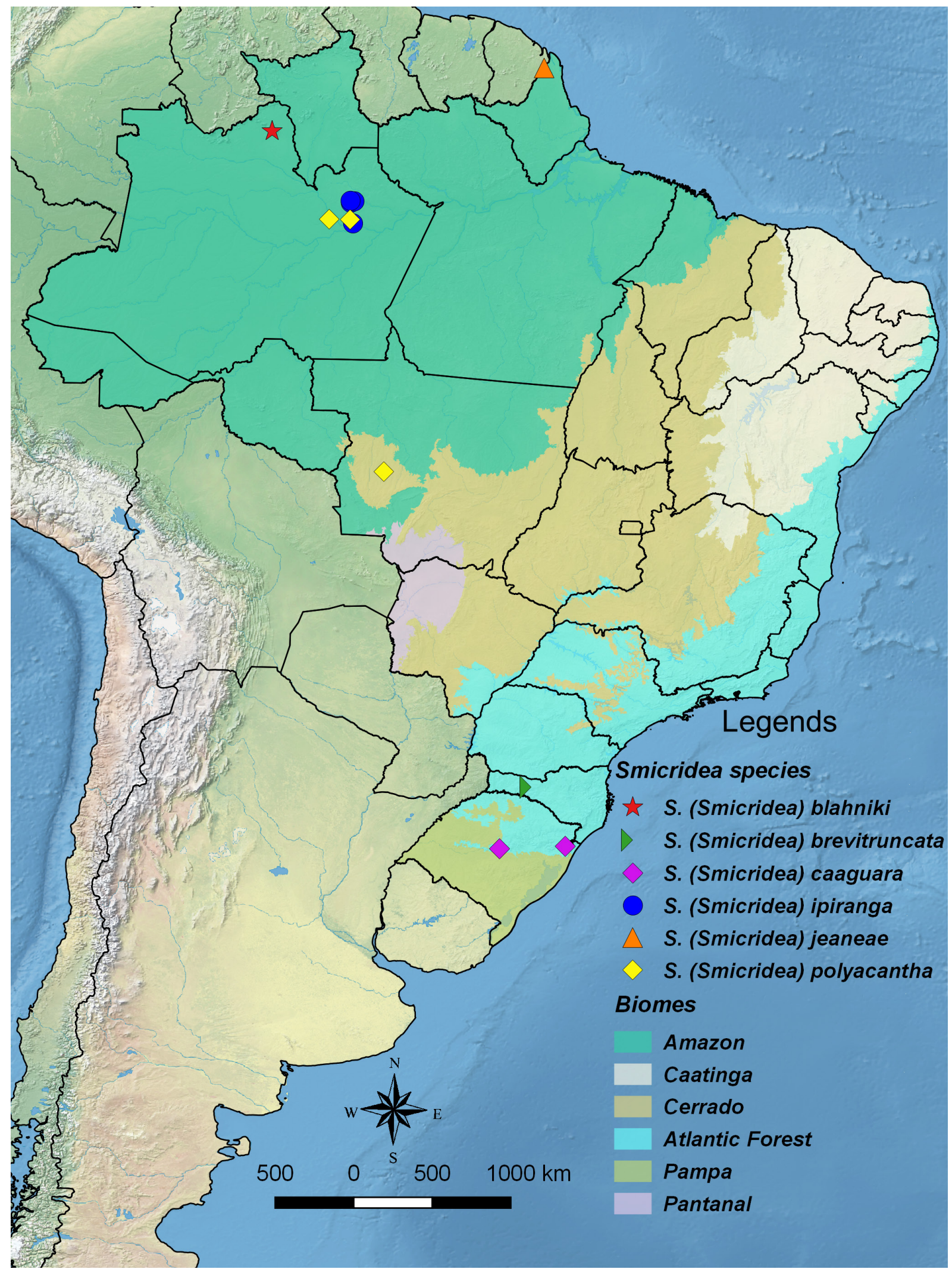

Fig. 3. Geographical distribution map for the new species of Smicridea McLachlan, 1871 treated in this study. 


\section{Bionomics}

The males of S. blahniki sp. nov. were collected near a $1^{\text {st }}$ order stream, where the predominant vegetation is highland savanna with a minimum altitude of $1112 \mathrm{~m}$ a.s.l. (Fig 4A). This stream is located in the Serra do Aracá mountain range, northern Brazilian Amazon. The water in the stream was black and acidic ( $\mathrm{pH} 4.6)$, with low conductivity $\left(10 \mu \mathrm{Scm}^{-1}\right)$, and a water temperature of $22^{\circ} \mathrm{C}$. The stream was about $0.5 \mathrm{~m}$ wide, $0.30 \mathrm{~m}$ deep, with rocky bottoms characterized by boulders and slow-flowing water.

\section{Distribution (Fig. 3)}

Brazil: Amazon (Amazonas).

Smicridea (Smicridea) brevitruncata Desiderio, Pes \& Hamada sp. nov. urn:lsid:zoobank.org:act:47DD9364-4029-4B7C-A3EC-08B52BC03778

Figs 3, 4B, 5-6

\section{Diagnosis}

Smicridea brevitruncata sp. nov. belongs to the albosignata complex of Flint (1981). It is most similar to $S$. riita Flint, 1981 from Venezuela based on the obliquely truncated apex of tergite $\mathrm{X}$ in dorsal view. However, in S. brevitruncata sp. nov. the apical segment of the inferior appendage is thick and short, and the truncated apex has numerous medium-sized, acuminate setae on the mesal margin, whereas in $S$. riita it is long, slender, with an acute apex, bearing numerous short, thin setae. Furthermore, the new species can be diagnosed by the basal segment of the inferior appendage having four long, stout apical spine-like setae, two dorsal and two on the mesal margin, and by the shape of the phallotremal sclerite, mainly in dorsal view. Additionally, S. brevitruncata sp. nov. differs from all other species of $S$. (Smicridea) by the absence of the internal reticulate sacs on abdominal segments VI and VII.

\section{Etymology}

The specific epithet is an allusion to the characteristics of the inferior appendages, which are short and apically truncated. Derived from the Latin words, 'brevi' = 'short' and 'truncata' = 'piece cut off, tip, end'.

\section{Material examined}

\section{Holotype}

BRAZIL - O; $^{\prime}$ Santa Catarina, Ponte Serrada, BR-282, Rio Irani, Parque dos Butieiros; 26 $6^{\circ} 5^{\prime} 49.2^{\prime \prime}$ S, 51'52'29.3" W; 1022 m a.s.1.; 5 Sep. 2009; N. Hamada, A.M.O. Pes and J.O. Silva leg.; white sheet with an LED light; INPA-TRI 000108.

\section{Paratypes}

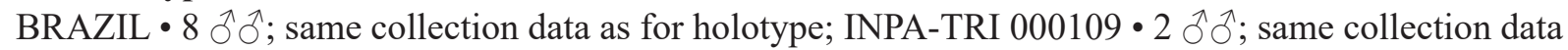
as for holotype; DZUP $\bullet 2 \hat{\jmath}$; same collection data as for holotype; DZRJ $\bullet 2 \hat{\jmath}$; same collection data as for holotype; MZUSP.

\section{Description}

Adult male (Figs 5-6)

FOREWING LENGTH. $4.52-5.49 \mathrm{~mm}($ mean $=4.75 \mathrm{~mm}, \mathrm{SD}=0.37, \mathrm{n}=5)$.

CoLOR. General color dark brown (in alcohol) (Fig. 5A). Antennae brown (Fig. 5A). Head dark, with grayish to black setae on dorsum (Fig. 5B-C); dorsally with slightly pronounced median suture; with five setal warts; anteromesal wart small, rounded; anterolateral pair undivided, weakly delimited; posterolateral pair large, ovoid (Fig. 5C). Maxillary palp with segments $1-4$ increasing gradually about $0.8 \times$ in size 

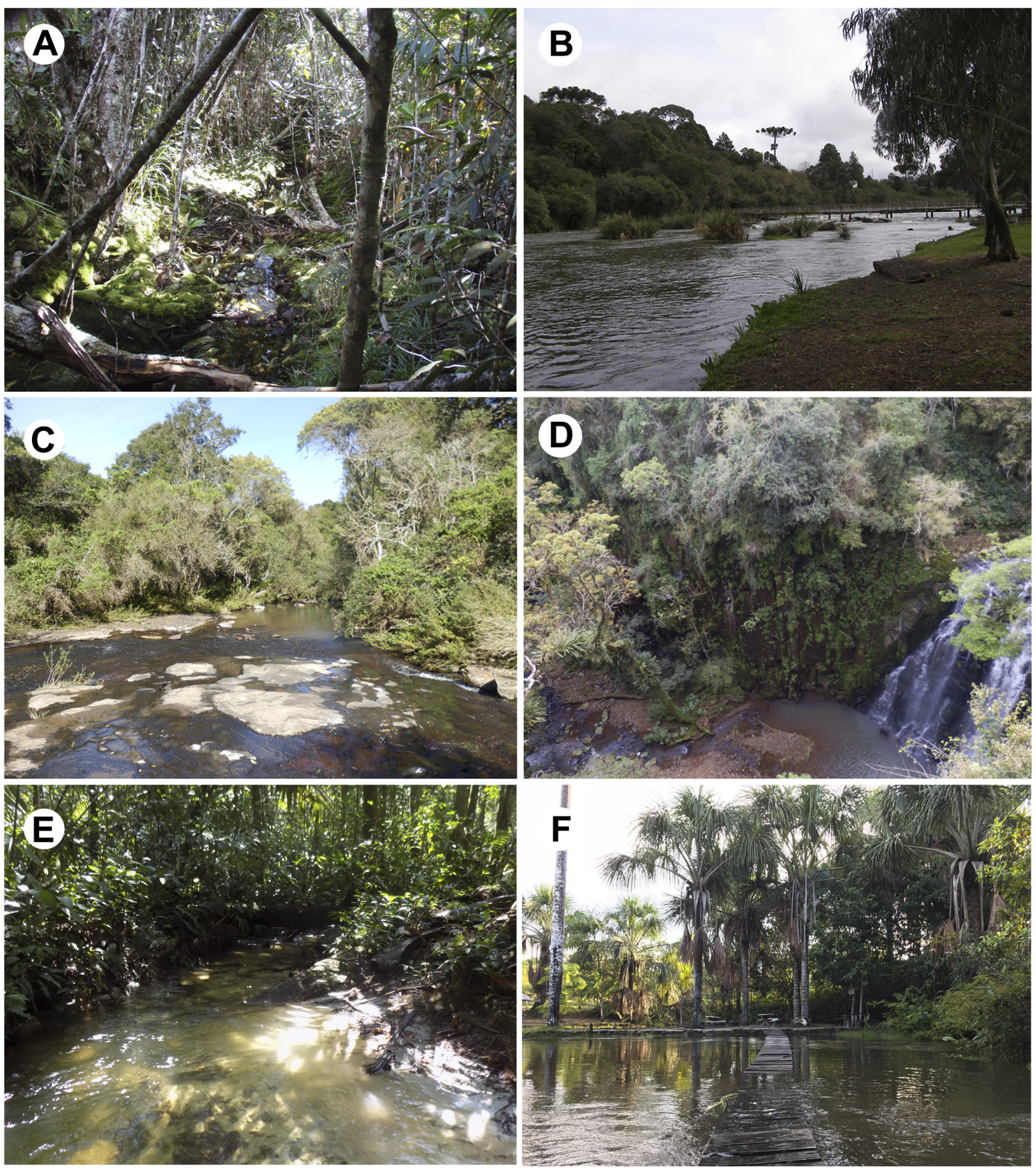

Fig. 4. Habitats of the new species of Smicridea McLachlan, 1871 treated in this study: A. First-order stream, Amazonas, Brazil, collection site of Smicridea (Smicridea) blahniki Desiderio, Pes \& Hamada sp. nov. B. Rio Irani, Santa Catarina, Brazil, collection site of $S$. (S.) brevitruncata Desiderio, Pes \& Hamada sp. nov. C. Arroio Lajeado, Rio Grande do Sul, Brazil, collection site of $S$. (S.) caaguara Desiderio, Pes \& Hamada sp. nov. holotype. D. Cascata Raddatz, Arroio Teotônica, Rio Grande do Sul, Brazil, collection site of $S$. (S.) caaguara sp. nov. paratype. E. Igarapé Ipiranga, Amazonas, Brazil, collection site of $S$. (S.) ipiranga Desiderio, Pes \& Hamada sp. nov. F. Balneário Km 18.5, Amazonas, Brazil, collection site of $S$. (S.) polyacantha Desiderio, Pes \& Hamada sp. nov. 

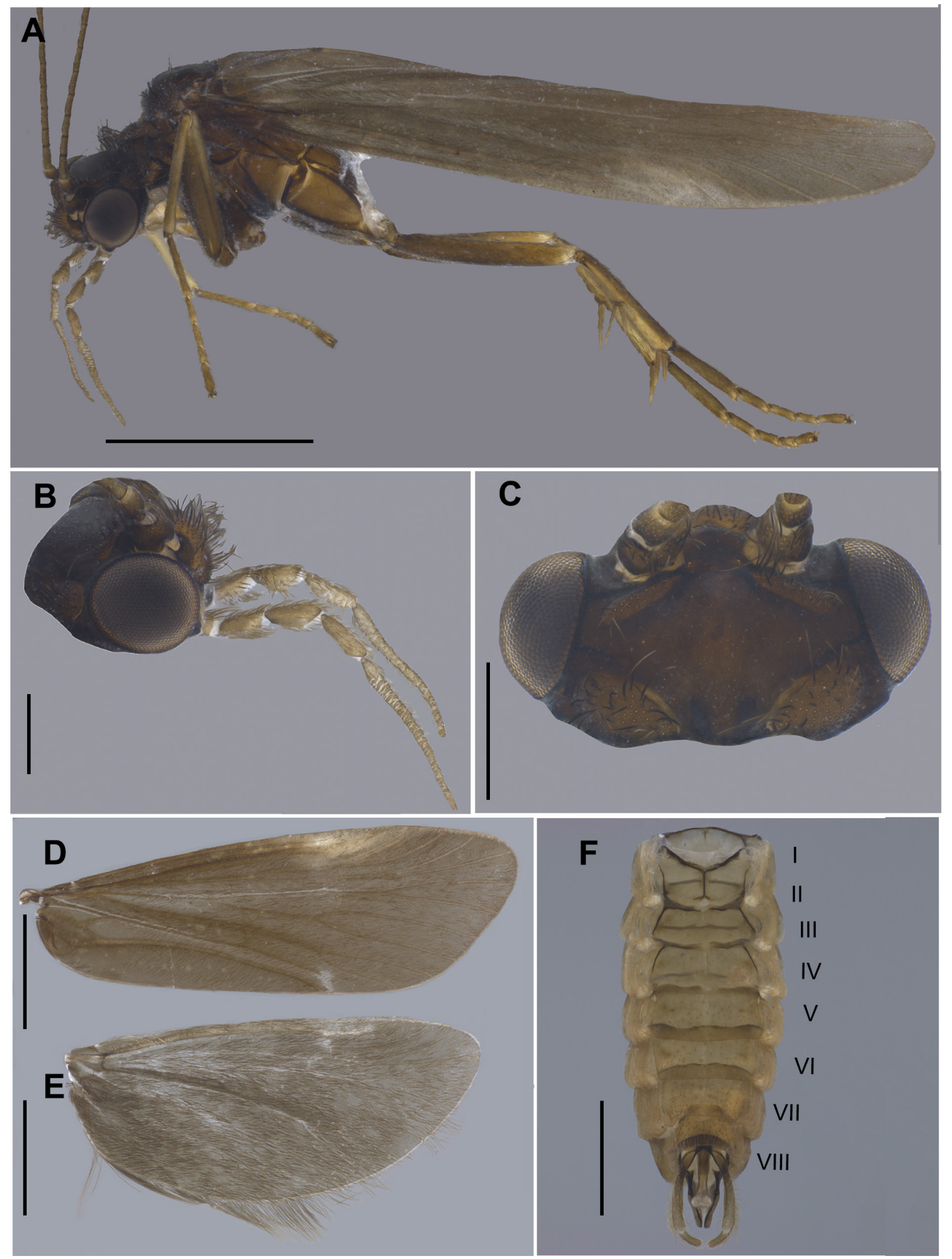

Fig. 5. Smicridea (Smicridea) brevitruncata Desiderio, Pes \& Hamada sp. nov., holotype, $\widehat{\jmath}$ (INPA-TRI 000108). A. Lateral habitus (in alcohol). B. Head, right lateral view. C. Head, dorsal view. D. Forewing, right dorsal view. E. Hind wing, right dorsal view. F. Abdomen, ventral view. Scale bars in $\mathrm{mm}: \mathrm{A}=2 ; \mathrm{B}-\mathrm{C}=0.5 ; \mathrm{D}-\mathrm{F}=1$. 
toward more apical segments, segment 5 long, about $1.2 \times$ as long as all previous segments combined (Fig. 5B). Thorax dark brown, covered with brown setae; legs brown, with mid-leg tarsi yellowish (Fig. 5A). Wing venation typical for subgenus (Fig. 5D-E). Forewings, in alcohol, uniformly fuscous, faintly marked with transverse band subapically on pterostigma reaching base of R4+5 and small spot on apex of $\mathrm{Cu} 2$ (Fig. 5D). Sternum V with anterolateral glandular processes slightly shorter than sternum. Abdominal segments VI and VII without pairs of internal reticulate sacs (Fig. 5F).

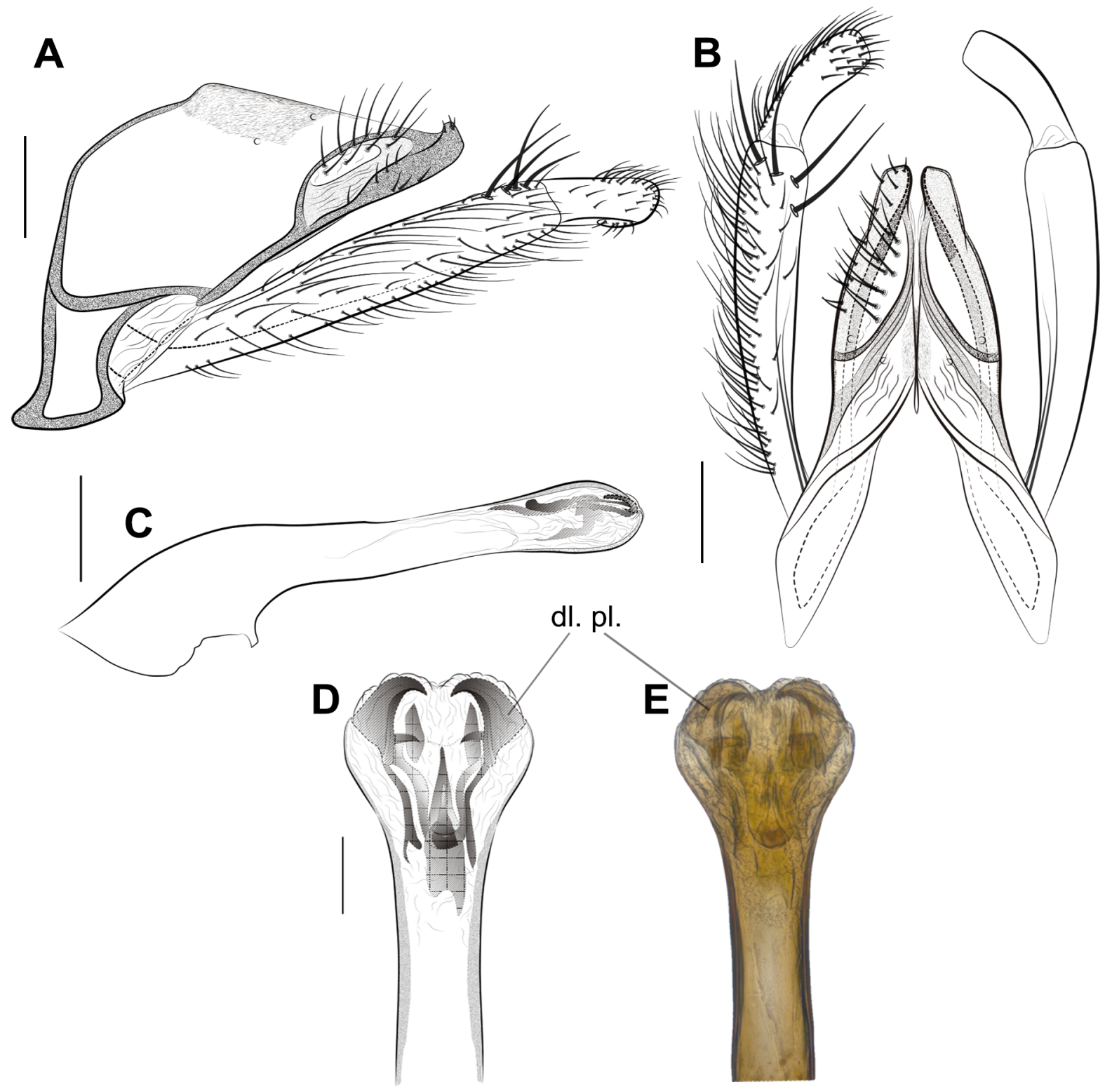

Fig. 6. Smicridea (Smicridea) brevitruncata Desiderio, Pes \& Hamada sp. nov., male terminalia, holotype (INPA-TRI 000108). A. Terga IX, X and inferior appendages, lateral view. B. Same, dorsal view. C. Phallic apparatus, lateral view. D. Apex of phallic apparatus, dorsal view. E. Apex of phallic apparatus (photograph). Scale bars in mm: A-C $=0.1$; D-E $=0.05$. 
Male Genitalia (Fig. 6). Segment IX in lateral view with anterolateral margin straight, strongly sclerotized (Fig. 6A); posterodorsal margin bearing small spicules, distributed in two subtriangular bands (Fig. 6B). Tergum X elongate; in lateral view, ventrolateral margin strongly sclerotized, with 10 to 12 short, stout setae on apical third; apex produced and upturned (Fig. 6A); in dorsal view, lateral margin slightly rounded; dorsomesal setose area bearing 10 medium-sized, thin setae; divided apicomesally by V-shaped incision about $1 / 3$ its length; apex of tergite obliquely truncated, with about three short, thin setae (Fig. 6B). Inferior appendages 2-segmented; basal segment long, slightly inflated distally, covered with long, thin setae, with four long, stout apical spine-like setae, two dorsal and two on mesal margin; apical segment short, about $1 / 4$ as long as basal segment, thick, slightly curved medially, apex truncated with numerous medium-sized, acuminate setae on mesal margin (Fig. 6B). Phallic apparatus long and tubular; basal section, in lateral view, enlarged, $4 \times$ diameter of phallotheca at its narrowest point, forming an angle of about $113^{\circ}$ with apical section; median section of phallotheca straight, without processes (Fig. 6C); apex enlarged, with pair of claw-shaped internal dorsolateral plates, longer than basal width, curved mesally and directed posterad; endothecal membranes without spines; phallotremal sclerite, in dorsal view, distinct, strongly sclerotized, proximal region with bifid base and pointed apex, distally with pair of subtriangular, toothlike structures, which are overlapped by pair of slender, curved mesad processes (Fig. 6D-E); in lateral view, proximal region with small middorsal lobe, distally directed downward (Fig. 6C). Ejaculatory duct of endophallus, in lateral view, distinct, slightly sclerotized (Fig. 6C).

\section{Bionomics}

This species was collected near a large fast-flowing river about $20 \mathrm{~m}$ wide, located at $1022 \mathrm{~m}$ a.s.l. in the southern part of the Brazilian Atlantic Forest (Fig 4B). In this region the predominant vegetation is Mixed Ombrophilous Forest composed mainly of Araucaria angustifolia (Bertol.) Kuntze (Araucariaceae), with intense agricultural and pasture activities.

\section{Distribution (Fig. 3)}

Brazil: Atlantic Forest (Santa Catarina).

Smicridea (Smicridea) caaguara Desiderio, Pes \& Hamada sp. nov. urn:1sid:zoobank.org:act:6BC132ED-63EA-4E0C-A18F-7D2A367B0C0E

Figs 3, 4C-D, 7-8

\section{Diagnosis}

This new species is another member of the albosignata complex; it is most similar to the nominal species $S$. albosignata based on the enlarged, slightly bifid apex of the apical segment of the inferior appendage. However, the lateral margin of tergum $\mathrm{X}$ in the new species is rounded in dorsal view, while in $S$. albosignata this structure is straight. Both species also differ in the shape of the tergum X apex: in $S$. albosignata it is acute in dorsal view, while in $S$. caaguara sp. nov. it is rounded. Additionally, S. albosignata has the apex of tergum $\mathrm{X}$ with a subtriangular apicomesal flap directed laterad in dorsal view, while in $S$. caaguara sp. nov. this flap is absent. The new species also can be recognized by the distinct and complex phallotremal sclerite in dorsal view.

\section{Etymology}

The specific epithet is a reference to the indigenous people known as caaguaras, first inhabitants of the São Francisco de Paula municipality, which is the type locality of this species. This name is used as a noun in apposition. 


\section{Material examined}

Holotype

BRAZIL • \} \text { ; Rio Grande do Sul, São Francisco de Paula, Floresta Nacional São Francisco de Paula, Arroio } Lajeado; 29²5'57.01" S, 50²2'22.5" W; 832 m a.s.1.; 30 Aug.-2 Sep. 2015; N. Hamada, C.J. Benetti, G.P. Dantas and A.M.O. Pes leg.; INPA-TRI 000110.

\section{Paratype}

BRAZIL • 1 `ં; Rio Grande do Sul, Agudo, Cascata Raddatz, Arroio Teotônia; 29³5'12.05" S, 53¹0'49.8" W; 248 m a.s.1.; 25 Aug. 2015; N. Hamada, C.J. Benetti, G.P. Dantas and A.M.O. Pes leg.; INPA-TRI 000111.

\section{Description}

Adult male (Figs 7-8)

FOREWING LENGTH. 4.70, $5.92 \mathrm{~mm}(\mathrm{n}=2)$.

CoLor. General color dark brown (in alcohol) (Fig. 7A). Antennae brown (Fig. 7A). Head dark brown, with brown setae on dorsum (Fig. 7B-C); dorsally with weakly pronounced median suture; with five setal warts; anteromesal wart small, rounded; anterolateral pair undivided, weakly delimited; posterolateral pair large, ovoid (Fig. 7C). Maxillary palp with segments $1-4$ increasing gradually about $0.8 \times$ in size toward more apical segments, segment 5 long, about $1.2 \times$ as long as all previous segments combined (Fig. 7B). Thorax dark brown, covered with brown setae; legs brown, with mid-leg tarsi yellowish (Fig. 7A). Wing venation typical for subgenus (Fig. 7D-E). Forewings, in alcohol, grayish to dark brown, with white transverse band subapically on pterostigma reaching base of R $4+5$ and small white spot on apex of $\mathrm{Cu} 2$ (Fig. 7D). Sternum V with anterolateral glandular processes slightly longer than sternum. Abdominal segments VI and VII with 2 pairs of internal glands, both pairs longer than their segments (Fig. 7F).

Male Genitalia (Fig. 8). Segment IX in lateral view with anterolateral margin nearly straight, weakly sclerotized (Fig. 8A); posterodorsal margin bearing small spicules, distributed in two dark, narrow parallel bands (Fig. 8B). Tergum X elongate; in lateral view, ventrolateral margin strongly sclerotized, with eight to 10 medium-sized, thin setae on apical third; apex produced and upturned (Fig. 8A); in dorsal view, lateral margin rounded; dorsomesal setose area bearing six to eight medium-sized, thin setae; divided apicomesally by $\mathrm{V}$-shaped incision about $1 / 3$ its length; apex of tergite rounded, with about three short, thin setae (Fig. 8B). Inferior appendages 2-segmented; basal segment long, slightly inflated distally, covered with long, thin setae, with pair of long, stout apical spine-like setae on mesal margin; apical segment short, about $1 / 2$ as long as basal segment, thick, curved medially, apex enlarged and slightly bifid with numerous short, acuminate setae on mesal margin (Fig. 8B). Phallic apparatus long and tubular; basal section, in lateral view, enlarged, $3 \times$ diameter of phallotheca at its narrowest point, forming an angle of about $105^{\circ}$ with apical section; median section of phallotheca straight, with dorsal periphalic cap sclerotized and flattened (Fig. 8C); apex enlarged, with pair of claw-shaped internal dorsolateral plates, longer than basal width, curved mesally and directed posterad; endothecal membranes without spines; phallotremal sclerite, in dorsal view, distinct, strongly sclerotized, proximal region slender, rod-like, divided distally in two subtriangular lateral flaps (Fig. 8D-E); in lateral view, proximal region with small middorsal lobe, distally directed downward (Fig. 8C). Ejaculatory duct of endophallus, in lateral view, distinct, slightly sclerotized (Fig. 8C).

\section{Bionomics}

The males of S. caaguara sp. nov. were collected near medium-sized streams, about $5.0 \mathrm{~m}$ wide, located in the Pampa-Atlantic Forest transition zone in the state of Rio Grande do Sul. The vegetation of the collections sites varies from Grassy-Woody Steppe (Arroio Lageado - Rio dos Sinos Basin, Fig 4C) to 




Fig. 7. Smicridea (Smicridea) caaguara Desiderio, Pes \& Hamada sp. nov., holotype, $ð$ (INPA-TRI 000110). A. Lateral habitus. B. Head, right lateral view. C. Head, dorsal view. D. Forewing, right dorsal view. E. Hind wing, right dorsal view. F. Abdomen, ventral view. Scale bars in mm: A =2; B-C = 0.5; D-F =1. 
Seasonal Deciduous Forest (Arroio Teotônia - Rio Jacuí Basin, Fig 4D). The streams have bedrock and fast-flowing water, with cloudy and alkaline water ( $\mathrm{pH} 7.9)$, conductivity $25-50.4 \mu \mathrm{Scm}^{-1}$, and water temperatures of $15-16.4^{\circ} \mathrm{C}$.

\section{Distribution (Fig. 3)}

Brazil: Atlantic Forest (Rio Grande do Sul).

A
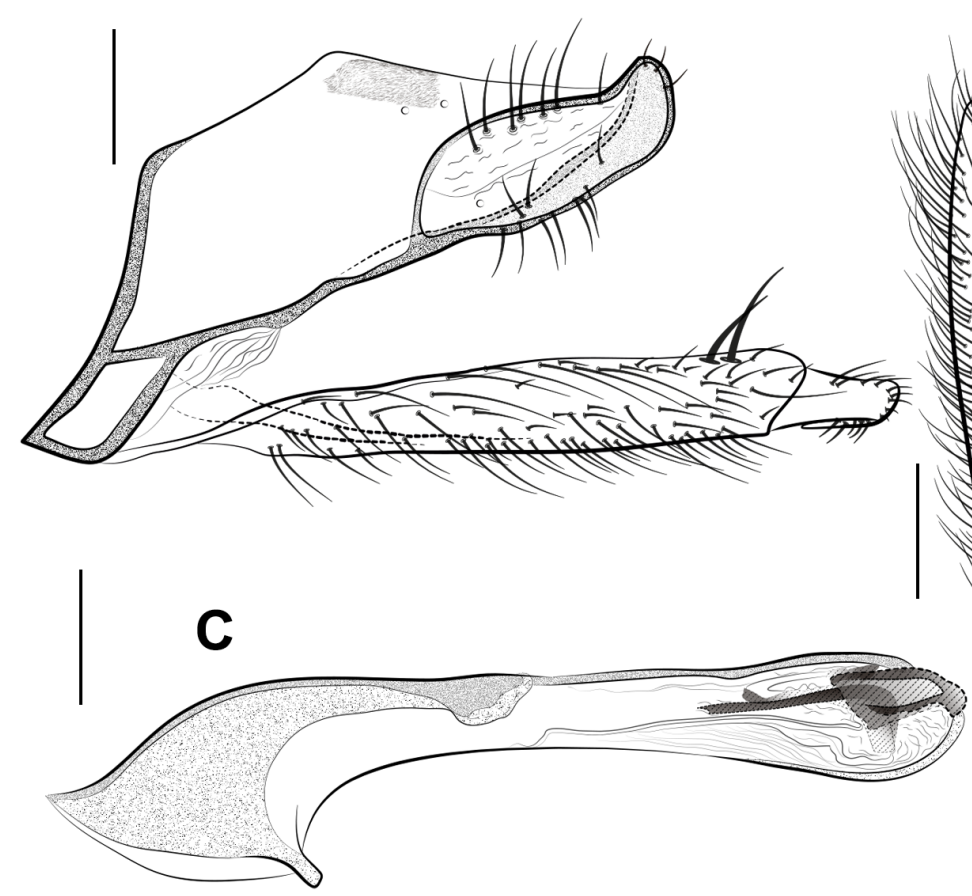

B

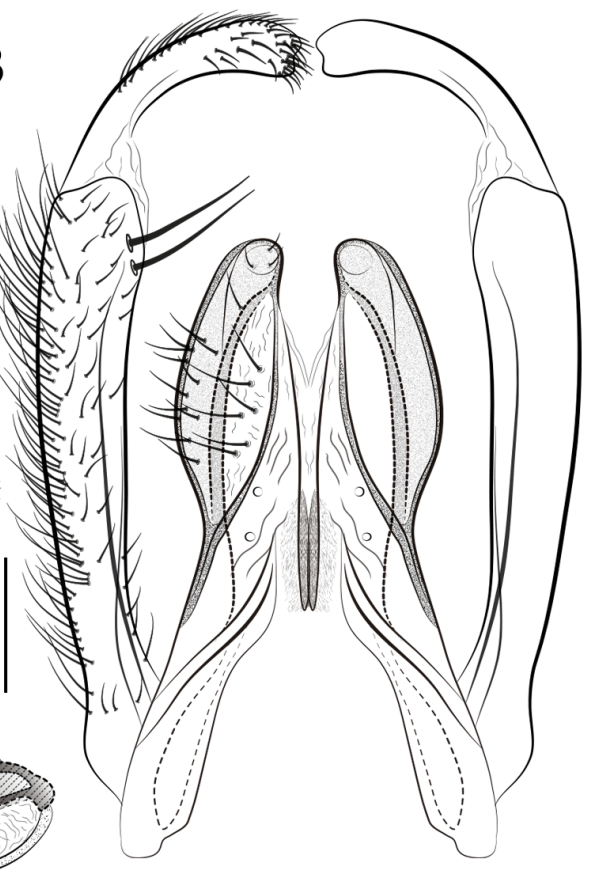

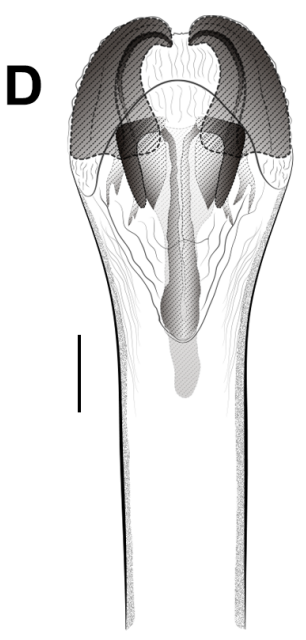

E

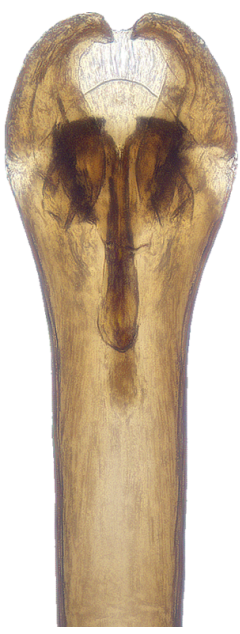

Fig. 8. Smicridea (Smicridea) caaguara Desiderio, Pes \& Hamada sp. nov., male terminalia, holotype (INPA-TRI 000110). A. Terga IX, X and inferior appendages, lateral view. B. Same, dorsal view. C. Phallic apparatus, lateral view. D. Apex of phallic apparatus, dorsal view. E. Apex of phallic apparatus (photograph). Scale bars in $\mathrm{mm}: \mathrm{A}-\mathrm{C}=0.1 ; \mathrm{D}-\mathrm{E}=0.05$. 
Smicridea (Smicridea) ipiranga Desiderio, Pes \& Hamada sp. nov. urn:lsid:zoobank.org:act:1E07D339-6A5A-4E95-A76D-A94339AD91AC

Figs 3, 4E, 9-10

\section{Diagnosis}

This new species can be assigned to the fasciatella complex. Smicridea ipiranga sp. nov. is similar to S. varia (Banks, 1913), S. lacanha Bueno-Soria \& Hamilton, 1986, and S. catherinae Blahnik, 1995 based on the shape of the apical segment of the inferior appendage, which is slender, strongly curved medially and has a pointed apex. These four species also have a single long, stout apical spine-like seta on the internal margin of the basal segment of the inferior appendage. However, S. ipiranga sp. nov. can be distinguished from its congeners by its diminutive size (on average $3.55 \mathrm{~mm}$ ); the most similar species in the complex are twice its size on average: $S$. catherinae (about $6.0 \mathrm{~mm}$ ), S. lacanha (about $7.9 \mathrm{~mm}$ ), and $S$. varia (about $6.15 \mathrm{~mm}$ ). Additionally, the new species has the phallotremal sclerite with the distal region M-shaped in dorsal view, while in S. catherinae, S. lacanha, and S. varia, this sclerite is Y-shaped.

\section{Etymology}

The specific epithet is a reference to the Ipiranga Stream, located in the Reserva Florestal Adolpho Ducke, where the type specimen was collected. This name is used in apposition.

\section{Material examined}

Holotype

BRAZIL - O’; Amazonas, Manaus, Reserva Florestal Adolpho Ducke, Igarapé Ipiranga; 0258'53.6" S, 5954'24.4" W; 95 m a.s.1.; 30 Jun.-2 Jul. 2015; A.M.O. Pes, G.R. Desiderio, P. Barcelos-Silva and W. Xavier leg.; Pennsylvania trap; INPA-TRI 000112.

\section{Paratypes}

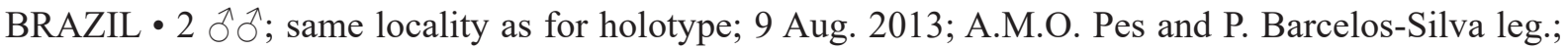
white sheet with an LED light; INPA-TRI $000113 \cdot 3$ of; same collection data as for holotype; Malaise

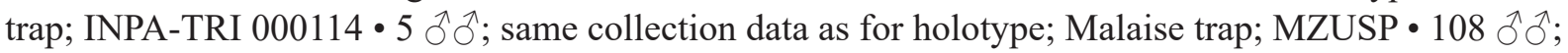
same collection data as for holotype; INPA-TRI 000115 • 1 ते; Presidente Figueiredo, AM-240, Km 13, Corredeira da Dona Maroca; 02 02'00.1" S, 5951'45.1" W; 19 Apr. 2008; U.G. Neiss leg.; white sheet with an LED light; DZUP • 6 ồ; Presidente Figueiredo, Balneário Sossego da Pantera, Igarapé da Onça; $02^{\circ} 05^{\prime} 57^{\prime \prime} \mathrm{S}, 60^{\circ} 01^{\prime} 02^{\prime \prime} \mathrm{W}$; $92 \mathrm{~m}$ a.s.1.; 23 Aug. 2012; A.M.O. Pes leg.; white sheet with an LED light; DZRJ.

\section{Description}

Adult male (Figs 9-10)

FOREWING LENGTH. $3.40-3.62 \mathrm{~mm}($ mean $=3.55, \mathrm{SD}=0.07, \mathrm{n}=6)$.

CoLOR. General color dark brown (in alcohol) or black (pinned) (Fig. 9A). Antennae yellowish brown (Fig. 9A). Head dark, with white setae on dorsum (Fig. 9B-C); dorsally with weakly-pronounced median suture; with five setal warts; anteromesal wart small, rounded; anterolateral pair undivided, weakly delimited; posterolateral pair large, ovoid (Fig. 9C). Maxillary palp with segments 1-4 increasing gradually about $0.8 \times$ in size toward more apical segments, segment 5 long, about $1.2 \times$ as long as all previous segments combined (Fig. 9B). Thorax dark brown, covered with pale brown setae; legs dark brown, with mid-leg tarsi pale yellowish (Fig. 9A). Wing venation typical for subgenus (Fig. 9D-E). Forewings, in alcohol, brown, with white transverse band subapically on pterostigma reaching base of R4 +5 and small white spot on apex of $\mathrm{Cu} 2$ (Fig. 9D); pinned specimens with 2 transversal bands of white setae, one continuous band in proximal portion reaching from base of subcostal vein to apex of $1 \mathrm{~A}$, the other band 


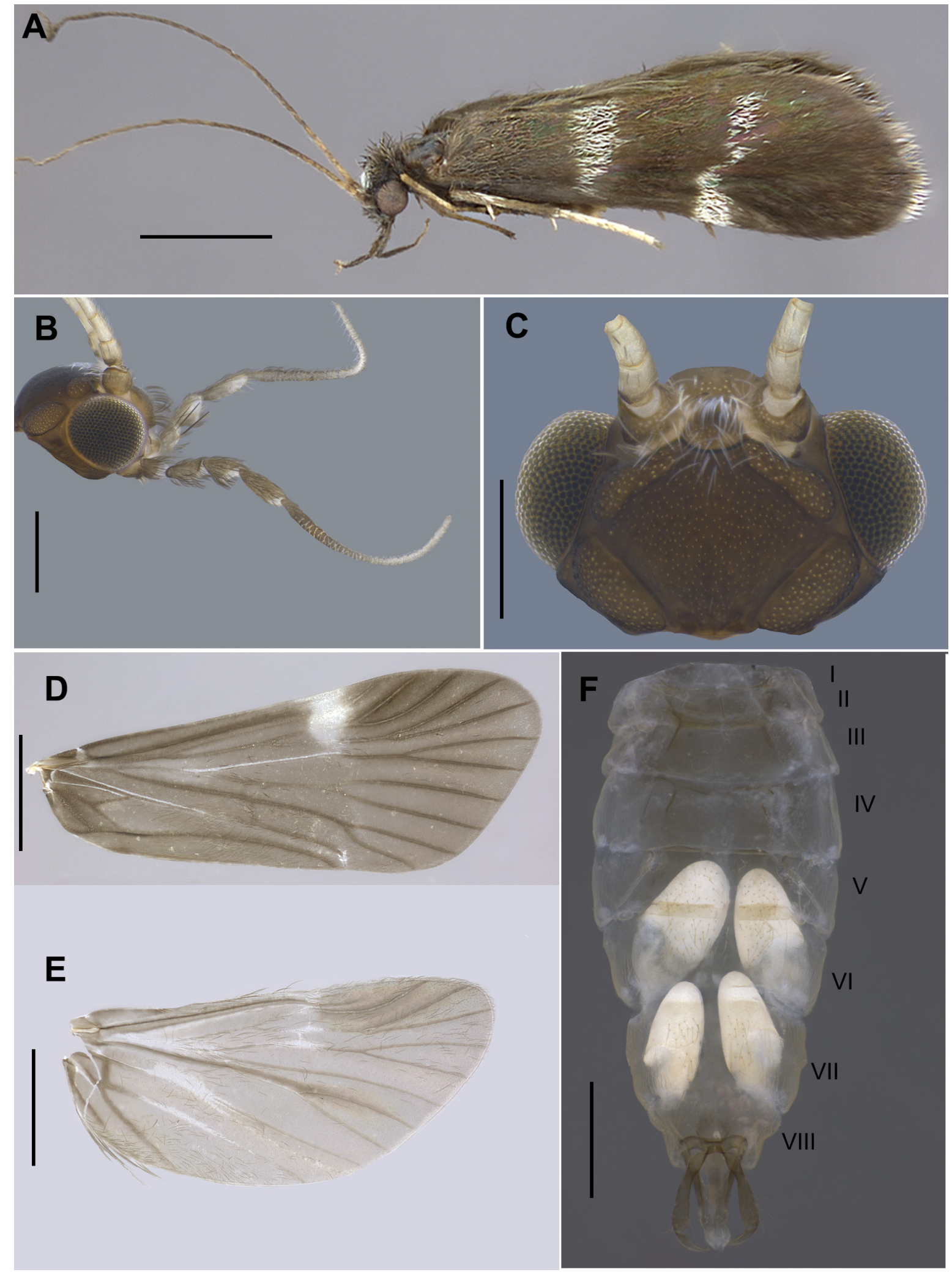

Fig. 9. Smicridea (Smicridea) ipiranga Desiderio, Pes \& Hamada sp. nov., holotype, $\widehat{\partial}$ (INPA-TRI 000112). A. Lateral habitus (in alcohol). B. Head, right lateral view. C. Head, dorsal view. D. Forewing, right dorsal view. E. Hind wing, right dorsal view. F. Abdomen, ventral view. Scale bars in mm: A = 2; B-C = $0.5 ; \mathrm{D}-\mathrm{F}=1$. 
discontinuous in distal portion reaching from pterostigma to apex of $\mathrm{Cu} 1$; apex of wing with fringe of white setae (Fig. 9A). Sternum V with anterolateral glandular processes slightly shorter than sternum. Abdominal segments VI and VII with 2 pairs of internal glands, both pairs longer than their containing segments (Fig. 9F).

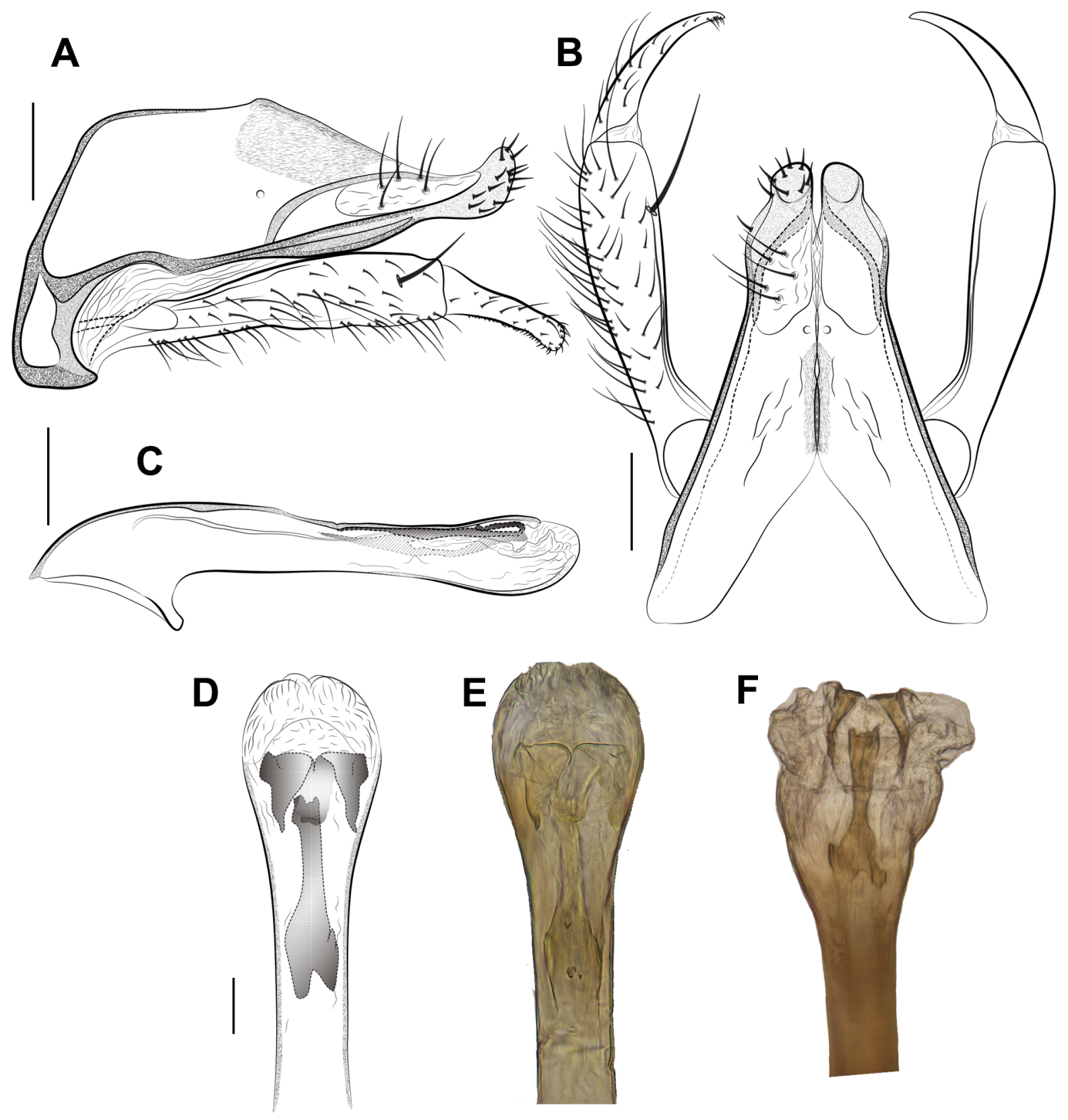

Fig. 10. Smicridea (Smicridea) ipiranga Desiderio, Pes \& Hamada sp. nov., male terminalia. A-E. Holotype (INPA-TRI 000112). A. Terga IX, X and inferior appendages, lateral view. B. Same, dorsal view. C. Phallic apparatus, lateral view. D. Apex of phallic apparatus, dorsal view. E. Apex of phallic apparatus (photograph). - F. Paratype (INPA-TRI 0115), apex of everted phallic apparatus (photograph), dorsal view. Scale bars in $\mathrm{mm}$ : A-C $=0.1 ; \mathrm{D}-\mathrm{F}=0.05$. 
Male Genitalia (Fig. 10). Segment IX in lateral view with anterolateral margin straight, strongly sclerotized (Fig. 10A); posterodorsal margin bearing small spicules, distributed in two subquadrate bands (Fig. 10B). Tergum $\mathrm{X}$ elongate; in lateral view, ventrolateral margin strongly sclerotized, with small subapical lobe; apex produced and upturned (Fig. 10A); in dorsal view, lateral margin slightly sinuous; dorsomesal setose area bearing five medium-sized, thin setae; divided apicomesally by V-shaped incision about $1 / 4$ its length; apex of tergite rounded, with large globose lobe and about eight short, stout setae (Fig. 10B). Inferior appendages 2-segmented; basal segment long, slightly inflated distally, covered with long, thin setae, with one long, stout apical spine-like seta on mesal margin; apical segment short, about $1 / 3$ as long as basal segment, slender, strongly curved medially, apex acute with numerous short, thin setae on mesal margin (Fig. 10B). Phallic apparatus long and tubular; basal section, in lateral view, enlarged, $2 \times$ diameter of phallotheca at its narrowest point, forming an angle of about $116^{\circ}$ with apical section; median section of phallotheca straight, without processes (Fig. 10C); apex slightly enlarged, without processes or plates; endothecal membranes without spines; phallotremal sclerite, in dorsal view, distinct, strongly sclerotized, proximal region enlarged and narrowing mesally, distal region M-shaped (Fig. 10D-E); in lateral view, aciculate (Fig. 10C). Ejaculatory duct of endophallus, in lateral view, distinct, slightly sclerotized (Fig. 10C). When endothecal membranes are everted, phallotremal sclerite divided into two disconnected parts, one long, apicomesal, rod-like, and the other with a pair of comma-shaped sclerites, distally slightly curved (Fig. 10F).

\section{Bionomics}

The males of $S$. ipiranga $\mathrm{sp}$. nov. were collected near streams in the central Amazon, mainly in a $2^{\text {nd }}$ order stream (Igarapé Ipiranga) located in the Reserva Florestal Adolpho Ducke, an area of primary Amazon rainforest of about $100 \mathrm{~km}^{2}$ that is under the protection of the Instituto Nacional de Pesquisas da Amazônia (INPA). The riparian vegetation along this stream is about $2.4 \mathrm{~m}$ wide and $0.29 \mathrm{~m}$ deep, with a sandy bottom, and a medium-speed water flow (Fig 4E). Its water is clear and acidic ( $\mathrm{pH} 5.1$ ), oxygen solubility levels are high $(6.9 \mathrm{mgL})$, electrical conductivity is low $\left(8.5 \mu \mathrm{Scm}^{-1}\right)$, and the average temperature is $25.6^{\circ} \mathrm{C}$. Specimens of S. ipiranga sp. nov. were also collected in medium-sized streams in the municipality of Presidente Figueiredo (Corredeira da Dona Maroca and Igarapé da Onça), 3.5-12.5 m in width, 0.19-0.44 m deep, with fast-flowing water. These streams were used for recreation (swimming and camping), with rocky bottoms characterized by black and acidic water ( $\mathrm{pH} 4.2-4.8$ ), low electrical conductivity $\left(10.9 \mu \mathrm{Scm}^{-1}\right)$, and a water temperature of $25^{\circ} \mathrm{C}$.

\section{Distribution (Fig. 3)}

Brazil: Amazon (Amazonas).

Smicridea (Smicridea) jeaneae Desiderio, Pes \& Hamada sp. nov. urn:1sid:zoobank.org:act:B3B2E393-F3E0-4FAD-8838-32481EB11877

Figs 3, 11-12

\section{Diagnosis}

Smicridea jeaneae sp. nov. also belongs to the albosignata complex. Among the species in this complex, it is most similar to $S$. bulbosa Flint, 1974 from Suriname based on the strong, parallel, pointed apicomesal lobes on tergum $\mathrm{X}$ and the short, slender apical segment of the inferior appendage with slightly acute apex. In both species the claw-shaped internal dorsolateral plates of the phallic apparatus are as long as the basal width, but in $S$. jeaneae sp. nov. the plates are straight mesally, while in $S$. bulbosa they are curved. In addition, the phallotremal sclerite of the phallic apparatus has a hastate shape distally in dorsal view and is kidney-shaped in lateral view in the new species, but is strap-like in dorsal view and rod-like in lateral view in S. bulbosa. Smicridea jeaneae sp. nov. can also be recognized by the three stout apical 
spine-like setae on the basal segment of the inferior appendage, one long seta dorsally and two mediumsized setae on the mesal margin.

\section{Etymology}

This new species is named in honor of Dr Jeane Marcelle Cavalcante do Nascimento (Instituto Nacional de Pesquisas da Amazônia, INPA - Brazil) for her valuable friendship, cooperation in the field and the laboratory, and in gratitude for her help in collecting material during the doctoral studies of the first author.

\section{Material examined}

\section{Holotype}

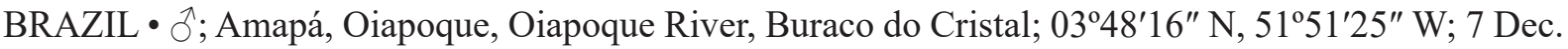
2018; M. Silva leg.; INPA-TRI 000116.

\section{Description}

Adult male (Figs 11-12)

FOREWING LENGTH. $6.37 \mathrm{~mm}(\mathrm{n}=1)$.

CoLor. General color dark brown (in alcohol) (Fig. 11A). Antennae yellowish brown (Fig. 11A). Head brown, with grayish to brown setae (Fig. 11B-C); dorsally with weakly pronounced median suture; with five setal warts; anteromesal wart small, rounded; anterolateral pair undivided, weakly delimited; posterolateral pair large, ovoid (Fig. 11C). Maxillary palp with segments 1-4 increasing gradually, about $0.8 \times$ in size toward the more apical segments, segment 5 long, about $1.2 \times$ as long as all previous segments combined (Fig. 11B). Thorax dark brown, covered with pale-brown setae; legs brown, with mid-leg tarsi yellowish (Fig. 11A). Wing venation typical for subgenus (Fig. 11D-E). Forewings, in alcohol, brown, with white transverse band subapically reaching base of $\mathrm{R} 2+3$, another arising on $\mathrm{M} 1+2$ and reaching base of $\mathrm{Cu} 1 \mathrm{a}+\mathrm{b}$, and small white spot on apex of Cu2 (Fig. 11D). Sternum V with anterolateral glandular processes slightly shorter than sternum. Abdominal segments VI and VII with 2 pairs of internal glands, both pairs longer than their containing segments (Fig. 11F).

Male Genitalia (Fig. 12). Segment IX in lateral view with anterolateral margin nearly straight, strongly sclerotized (Fig. 12A); posterodorsal margin bearing small spicules, distributed in two subtriangular bands (Fig. 12B). Tergum X elongate; in lateral view, ventrolateral margin strongly sclerotized, with three medium-sized, thin setae on apical third; apex with shallow notch, ending in a slender, straight lobe (Fig. 12A); in dorsal view, lateral margin slightly rounded; dorsomesal setose area bearing four mediumsized, thin setae; divided apicomesally by V-shaped incision about $1 / 2$ its length; apex of tergite rounded, with strong, pointed apicomesal lobe, each bearing three medium-sized, thin apical setae (Fig. 12B). Inferior appendages 2-segmented; basal segment long, slightly inflated distally, covered with long, thin setae, with group of stout apical spine-like setae (one very long dorsal seta and two long setae on mesal margin); apical segment short, about $1 / 3$ as long as basal segment, slender, strongly curved medially, apex slightly acute with numerous short, thin setae on mesal margin (Fig. 12B). Phallic apparatus long and tubular; basal section, in lateral view, enlarged, $4 \times$ diameter of phallotheca at its narrowest point, forming an angle of about $103^{\circ}$ with apical section; median section of phallotheca straight, without processes (Fig. 12C); apex enlarged, with pair of claw-shaped internal dorsolateral plates, as long as basal width, straight mesally and directed posterad; endothecal membranes without spines; phallotremal sclerite, in dorsal view, distinct, strongly sclerotized, with U-shaped proximal region and hastate distal region (Fig. 12D-E); in lateral view, dorsal region kidney-shaped, ventrally slender and sinuous (Fig. 12C). Ejaculatory duct of endophallus, in lateral view, distinct, slightly sclerotized (Fig. 12C). 


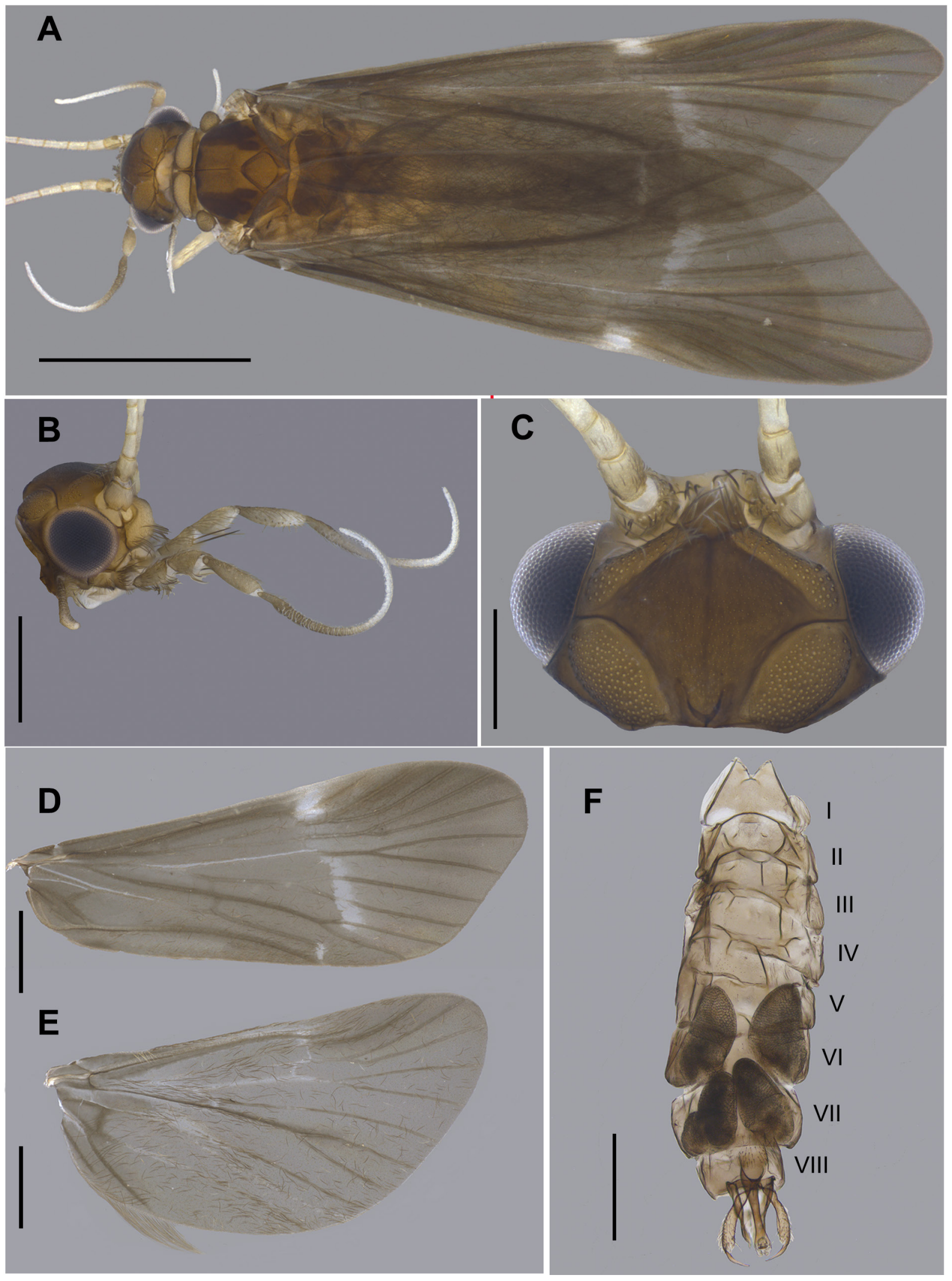

Fig. 11. Smicridea (Smicridea) jeaneae Desiderio, Pes \& Hamada sp. nov., holotype, $\widehat{\partial}$ (INPA-TRI 000116). A. Lateral habitus, pinned. B. Head, right lateral view. C. Head, dorsal view. D. Forewing, right dorsal view. E. Hind wing, right dorsal view. F. Abdomen, ventral view. Scale bars in mm: A, D-F =1; B-C =0.5. 


\section{Bionomics}

The only male specimen of $S$. jeaneae sp. nov. was collected near the Oiapoque River, at a place known as "Buraco do Cristal"; this river is about $400 \mathrm{~m}$ in width. The prevalent vegetation is Dense Ombrophilous Lowland Forest. The collection site is located in the northern-most part of the Brazilian Amazon.

\section{Distribution (Fig. 3)}

Brazil: Amazon (Amapá).

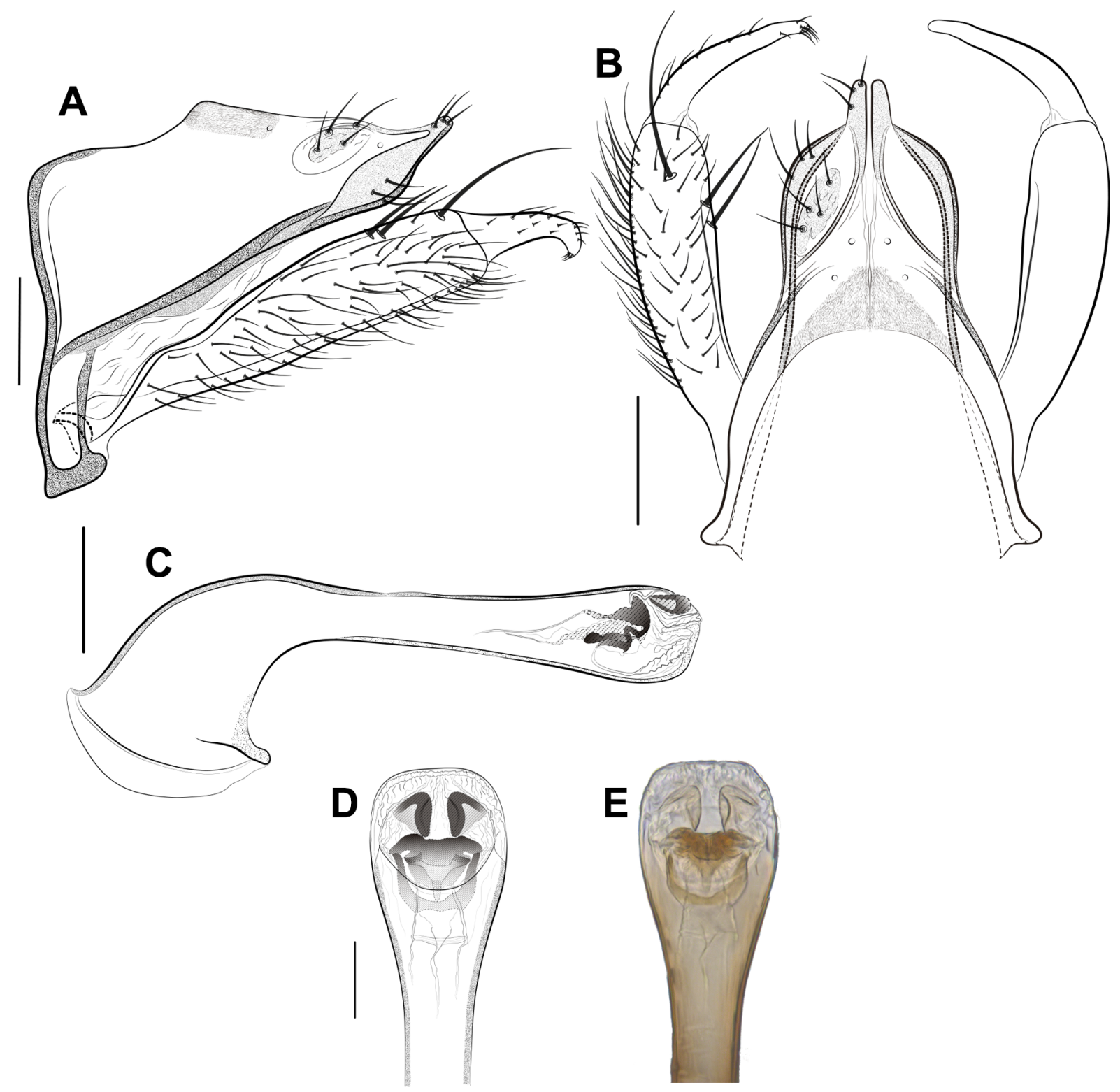

Fig. 12. Smicridea (Smicridea) jeaneae Desiderio, Pes \& Hamada sp. nov., male terminalia, holotype (INPA-TRI 000116). A. Terga IX, $X$ and inferior appendages, lateral view. B. Same, dorsal view. C. Phallic apparatus, lateral view. D. Apex of phallic apparatus, dorsal view. E. Apex of phallic apparatus (photograph). Scale bars in $\mathrm{mm}: \mathrm{A}-\mathrm{C}=0.1 ; \mathrm{D}-\mathrm{E}=0.05$. 
Smicridea (Smicridea) polyacantha Desiderio, Pes \& Hamada sp. nov. urn:1sid:zoobank.org:act:3D7EB67E-4896-419A-AC6C-A1171653B9F0

Figs 3, 4F, 13-14

\section{Diagnosis}

This new species is a distinct member of the fasciatella group due the presence of small endothecal spines on the apex of the phallic apparatus. Smicridea polyacantha sp. nov. and S. paranensis are the sole species in the group that share this character. However, the new species has 40 conical endothecal spines grouped in a V-shaped arrangement in dorsal view, while $S$. paranensis has numerous fine spines organized in four rows. Additionally, the apex of the apical segment of the inferior appendage is rounded in the new species and obliquely truncated in $S$. paranensis. The phallotremal sclerite has a proximal region that is bifid, curved downward in lateral view, and a dorsolateral projection on the distal region that is unique in $S$. polyacantha sp. nov.

\section{Etymology}

The specific epithet is an allusion to the large number of endothecal spines present on the apex of the phallus. Derived from the Greek words, 'poly' = 'very' or 'many' and 'akantha' = 'spine'.

\section{Material examined}

\section{Holotype}

BRAZIL - O'; Amazonas, Manaus, BR-174, Balneário Km 18.5; 0249'00.80" S, 6002'05.60" W; 33 m a.s.l.; 27 Oct. 2009; A.M.O. Pes, J.O. Silva and R. Boldrini leg.; white sheet with an LED light; INPA-TRI 000117.

\section{Paratypes}

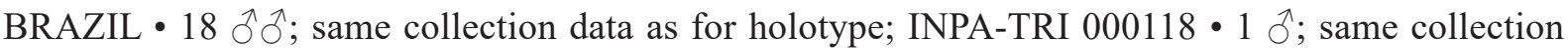
data as for holotype; 7 Apr. 2009; INPA-TRI $000119 \cdot 2 \widehat{\delta}$; same collection data as for holotype;

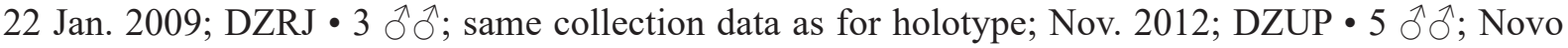
Airão, Igarapé Mato Grosso; 02 ${ }^{\circ} 9^{\prime} 03.8^{\prime \prime}$ S, 6055'47.1" W; $24-26$ Nov. 2014; R.L.F. Keppler and J.O. Silva leg.; Pennsylvania trap; MZUSP • 1 ơ; Mato Grosso, Sapezal, MT-235, Rio Papagaio, outside indigenous reserve; 13³3'39.5" S, 58²4'24.2" W; 473 m a.s.1.; 31 Oct.-1 Nov. 2012; N. Hamada and J.M.C. Nascimento leg.; Pennsylvania trap; INPA-TRI 000120.

\section{Description}

Adult male (Figs 13-14)

FoREWING LENGTH. 3.61-4.02 $\mathrm{mm}($ mean $=3.79, \mathrm{SD}=0.15, \mathrm{n}=6)$.

CoLOR. General color dark brown (in alcohol) (Fig. 13A). Antennae yellowish brown (Fig. 13A). Head dark brown, with brown setae on dorsum (Fig. 13B-C); dorsally with weakly pronounced median suture; with five setal warts; anteromesal wart small, rounded; anterolateral pair undivided, weakly delimited; posterolateral pair large, ovoid (Fig. 13C). Maxillary palp with segments 1-4 increasing gradually about $0.8 \times$ in size toward more apical segments, segment 5 long, about $1.2 \times$ as long as all previous segments combined (Fig. 13B). Thorax dark brown, covered with pale-brown setae; legs brown, with mid-leg tarsi yellowish (Fig. 13A). Wing venation typical for subgenus (Fig. 13D-E). Forewings, in alcohol, brown, with white transverse band subapically on pterostigma reaching base of R4+5 and small white spot on apex of $\mathrm{Cu} 2$ (Fig. 13D). Sternum V with anterolateral glandular processes slightly shorter than sternum. Abdominal segments VI and VII with 2 pairs of internal glands, both pairs as long as their containing segments (Fig. 13F). 


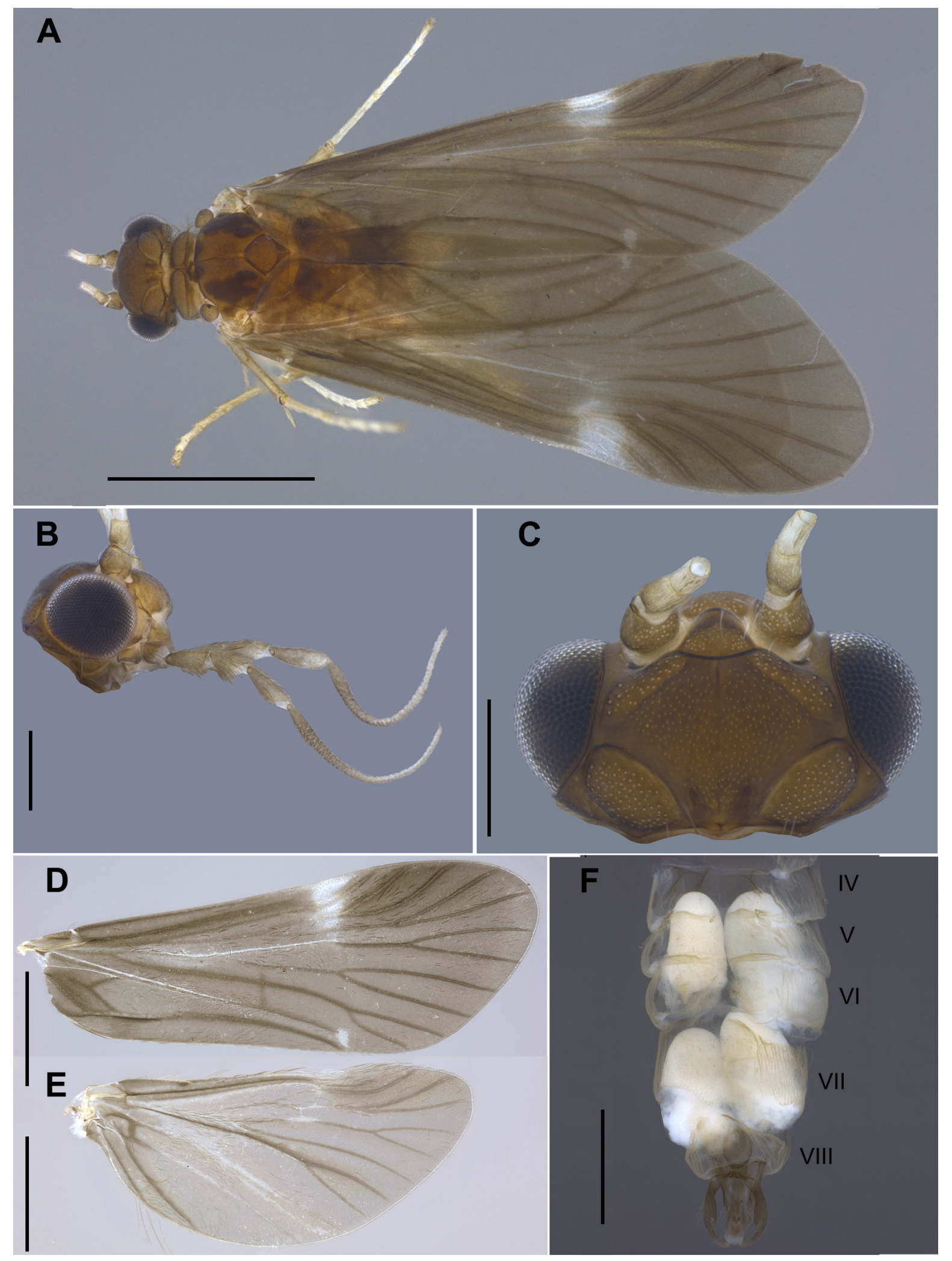

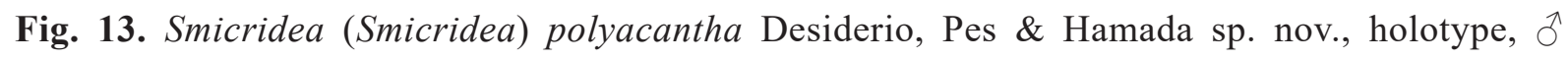
(INPA-TRI 000117). A. Dorsal habitus. B. Head, right lateral view. C. Head, dorsal view. D. Forewing, right dorsal view. E. Hind wing, right dorsal view. F. Abdominal segments IV-VIII, ventral view. Scale bars in $\mathrm{mm}: \mathrm{A}=2 ; \mathrm{B}-\mathrm{C}=0.5 ; \mathrm{D}-\mathrm{F}=1$. 

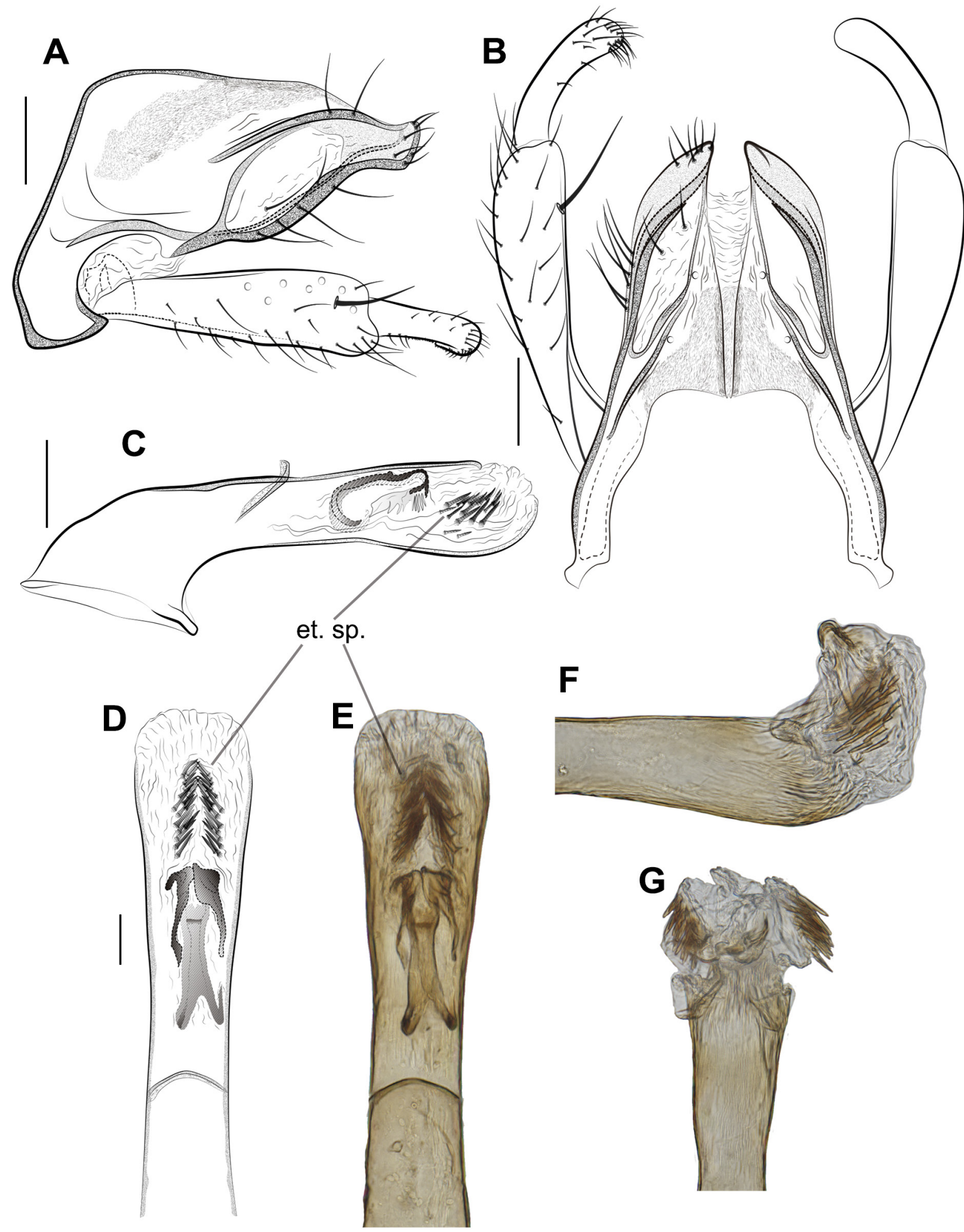

Fig. 14. Smicridea (Smicridea) polyacantha Desiderio, Pes \& Hamada sp. nov., male terminalia. A-E. Holotype (INPA-TRI 000117). A. Terga IX, X and inferior appendages, lateral view. B. Same, dorsal view. C. Phallus, lateral view. D. Apex of phallus, dorsal view. E. Apex of phallus (photograph). - F. Paratype (MZUSP), apex of everted phallus (photograph), lateral view. - G. Paratype (INPA-TRI 000119), apex of everted phallus (photograph), dorsal view. Scale bars in $\mathrm{mm}$ : $\mathrm{A}-\mathrm{C}=0.1 ; \mathrm{D}-\mathrm{G}=0.05$. 
Male Genitalia (Fig. 14). Segment IX in lateral view with anterolateral margin nearly straight, weakly sclerotized (Fig. 14A); posterodorsal margin bearing small spicules, distributed in two rounded bands (Fig. 14B). Tergum X elongate; in lateral view, ventrolateral margin slightly sclerotized, with five long, thin setae on apical third; apex produced and upturned (Fig. 14A); in dorsal view, lateral margin straight; dorsomesal setose area bearing two medium-sized, thin setae; divided apicomesally by a V-shaped incision about $1 / 2$ its length; apex of tergite slightly pointed, with small apicomesal lobe and about six mediumsized, thin setae (Fig. 14B). Inferior appendages 2-segmented; basal segment long, slightly inflated distally, covered with medium-sized, thin setae, with one long, stout subapical spine-like seta on mesal margin; apical segment short, about $1 / 3$ as long as basal segment, thick, slightly curved medially, apex rounded with numerous short, thin setae on mesal margin (Fig. 14B). Phallic apparatus long and tubular; basal section, in lateral view, enlarged, $3 \times$ diameter of phallotheca at its narrowest point, forming an angle of about $116^{\circ}$ with apical section; median section of phallotheca straight, with dorsal periphalic cap sclerotized, slender and upturned (Fig. 14C); apex slightly enlarged, without processes or plates; endothecal membranes with 40 small, conical spines, grouped in a V-shaped arrangement and directed posterad; phallotremal sclerite, in dorsal view, distinct, strongly sclerotized, proximal region bifid, curved downward in lateral view and directed posterad, distal region with dorsolateral projections more than half length of sclerite, broad apically, folding and touching dorsomesally, and with another pair of slender ventrolateral projections curved downward and directed anterad (Fig. 14D-E); in lateral view, proximal and distal regions hooked, not parallel in proximal region (Fig. 14C). Ejaculatory duct of endophallus, in lateral view, indistinct (Fig. 14C). When endothecal membranes are everted, phallotremal sclerite modified into two dorsolateral slender lobes, forked at apex, connected to a dorsomesal ring, and apical spines divided into two lateral lobes with 20 spines each, in lateral view, directed anterad (Fig. 14F-G).

\section{Bionomics}

This species was collected near medium-sized streams with slow flow in central Amazonia. The streams were strongly impacted by human activities, especially recreational use (swimming) and road building (Fig. 4F). These streams have sandy bottoms and are characterized by Dense Ombrophilous Forest Lowlands to Dense Ombrophilous Forest. Only one male of $S$. polyacantha sp. nov. was collected near a large river (Rio Papagaio) with fast-flowing water and a rocky bottom, located in the western part of the Brazilian Cerrado, where the vegetation is composed by Primary Savanna, Seasonal-Forest Savanna, and Wooded Savanna. The surroundings of this region are also strongly impacted by agricultural and pasture activities.

Distribution (Fig. 3)

Brazil: Amazon (Amazonas), Cerrado (Mato Grosso).

\section{New distributional records}

Smicridea (Smicridea) albosignata Ulmer, 1907

Fig. 15A

Smicridea albosignata Ulmer, 1907: 34 (type locality: Brazil, Santos; ZSZMH; đ̂). Smicridea maculata Banks, 1920: 359 (type locality: Brazil; MCZ; đ̂).

Smicridea albosignata - Weidner 1964: 97 (lectotype). — Denning \& Sykora 1968: 176 (ð’, redescription). — Marinoni \& Almeida 2000: 286 (distribution, biology). - Blahnik et al. 2004: 4 (distribution). - Paprocki et al. 2004: 10 (checklist). - Dumas et al. 2009: 359 (distribution). - Calor 2011: 321 (checklist). — Dumas \& Nessimian 2012: 14 (distribution). — Paprocki \& França 2014: 37 (checklist). — Holzenthal \& Calor 2017: 161 (catalog). — Vilarino \& Calor 2017: 512 (distribution). Smicridea maculata - Flint 1967: 13 (ð, redescription, to synonymy). 


\section{Material examined}

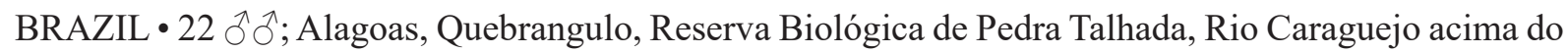
alojamento; $09^{\circ} 15^{\prime} 26^{\prime \prime}$ S, 36 $25^{\prime} 07.90^{\prime \prime}$ W; 21-28 Jun. 2014; A.P.M. Santos, D.M. Takiya, A.C. Domahovski and W.R.M. Souza leg.; Malaise trap; DZRJ 1 J ; Pernambuco; Tamandaré, Reserva Biológica Saltinho, Riacho Saltinho; $8^{\circ} 43^{\prime} 47^{\prime \prime} \mathrm{S}, 35^{\circ} 10^{\prime} 31^{\prime \prime} \mathrm{W} ; 50 \mathrm{~m}$ a.s.l.; 20 May 2018; R. Pereira-Silva, R.P. Lima and D.W.S. Gomes leg.; UV light pan trap; UFBA -1 万̃; Sergipe, Itabaiana, Parque Nacional da Serra de Itabaiana, Riacho Água Fria; $10^{\circ} 45^{\prime} 17^{\prime \prime}$ S, 37²0'32.40" W; 196 m a.s.1.; 19 Jun. 2014; A.P.M. Santos, D.M. Takiya, A.C. Domahovski and W.R.M. Souza leg.; Pennsylvania trap; DZRJ • 1 đ̇; Tocantins, Mateiros, Parque Estadual Jalapão, Cachoeira da Formiga; $10^{\circ} 20^{\prime} 58^{\prime \prime} \mathrm{S}, 46^{\circ} 28^{\prime 2} 2.1^{\prime \prime} \mathrm{W} ; 461 \mathrm{~m}$ a.s.l.; 17 Oct. 2008; A.R. Calor, R. Mariano and M. Pepinelli leg.; white sheet with an LED light; UFBA.

Distribution (Fig. 15A)

Brazil: Atlantic Forest (Alagoas [new record], Bahia [Vilarino \& Calor 2017], Paraná [Marinoni \& Almeida 2000], Pernambuco [new record], Rio de Janeiro [Ulmer 1907; Blahnik et al. 2004; Dumas et al. 2009; Dumas \& Nessimian 2012], São Paulo [Ulmer 1907], Sergipe [new record]), Cerrado (Distrito Federal [new record], Minas Gerais [Blahnik et al. 2004], Tocantins [new record]).

Smicridea (Smicridea) bivittata (Hagen, 1861)

Fig. 15B

Hydropsyche? bivittata Hagen, 1861: 291 (type locality: Panama; MCZ; ㅇ).

Wormaldia albata Navás, 1924: 75 (type locality: Costa Rica, La Caja; MNHNP; ㅇ).

Smicridea bivittata - Ross 1952: 33 (lectotype). — Flint 1967: 13 (つ); 1974a: 16 (ふ; ๆ; distribution;

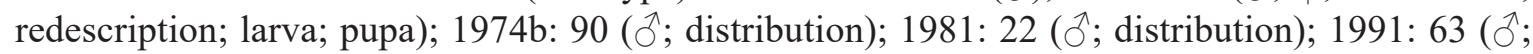
distribution); 1996: 82 (distribution). — Bueno-Soria \& Flint 1978: 207 (distribution). — Maes \& Flint 1988: 5 (distribution). — Holzenthal 1988: 70 (distribution). — Botosaneanu 1989: 205 (distribution); 2002: 94 (checklist). — Flint \& Reyes 1991: 481 (distribution). — Aguila 1992: 541 (distribution). — Botosaneanu \& Sakal 1992: 203 (distribution; ecology). — Botosaneanu \& Alkins-Koo 1993:

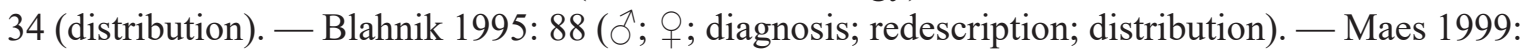
1186 (checklist). — Muñoz-Quesada 2000: 277 (checklist). — Botosaneanu \& Viloria 2002: 108 (distribution). - Blahnik et al. 2004: 4 (distribution). - Paprocki et al. 2004: 10 (checklist). — BuenoSoria et al. 2005: 75 (distribution). — Chamorro-Lacayo et al. 2007: 42 (checklist). - Albino et al. 2011: 3 (distribution). — Bueno-Soria \& Barba-Álvarez 2011: 356 (checklist). — Calor 2011: 321 (checklist). — Oláh \& Johanson 2012: 246 (distribution). — Paprocki \& França 2014: 37 (checklist). — Armitage et al. 2015: 5 (checklist). — Armitage \& Cornejo 2015: 194 (checklist). — Takiya et al. 2016: 77 (distribution). — Holzenthal \& Calor 2017: 164 (catalog). — Sganga \& Gibon 2018: 12 (distribution).

Wormaldia albata - Flint 1974a: 16 (to synonymy).

\section{Material examined}

BRAZIL • 1 đ ; Alagoas, Quebrangulo, Reserva Biológica de Pedra Talhada, Riacho Cafuringa below the dam; 09 $15^{\prime} 15.2^{\prime \prime}$ S, 36 $25^{\circ} 7^{\prime \prime}$ W; 20 Jun. 2014; A.P.M. Santos D.M. Takiya, A.C. Domahovski and W.R.M. Souza leg.; Pennsylvania trap; DZRJ • 1 đ ; Amazonas, São Gabriel da Cachoeira, BR-307,

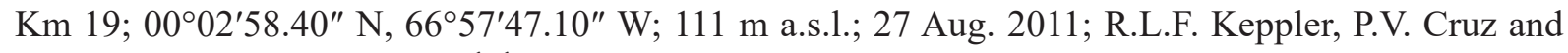
A. Fernandes leg.; INPA • 4 đ̂̀; Bahia, Igrapiúna, Reserva Ecológica Michelin, Córrego das Matas, $2^{\circ}$ ponte; 1349'24.6" S, 39 $10^{\prime} 9.0^{\prime \prime} \mathrm{W} ; 67 \mathrm{~m}$ a.s.1.; 25 Sep. 2013; Equipe Pafor leg.; UV light pan trap; UFBA 1 1 ; Tanquinho, Morro Branco, river cutting the road; $12^{\circ} 00^{\prime} 21.10^{\prime \prime} \mathrm{S}, 39^{\circ} 06^{\prime} 07.20^{\prime \prime} \mathrm{W}$; 119 m a.s.1.; 31 Jul. 2010; N. Hamada leg.; INPA • 1 đ̊; Distrito Federal, Brasília, Parque Nacional 
de Brasília, afluente $1^{\circ}$ ordem do Córrego Santa Maria; 1541'18.1" S, 4801'27.1" W; 1077 m a.s.1.;

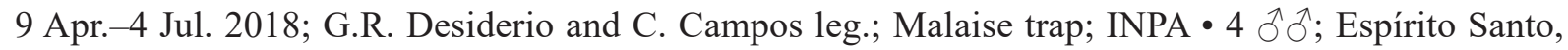
Castelo, Parque Estadual Mata das Flores, Cachoeira I; $20^{\circ} 36^{\prime} 42.7^{\prime \prime} \mathrm{S}, 41^{\circ} 10^{\prime} 12.1^{\prime \prime} \mathrm{W}$; $86 \mathrm{~m}$ a.s.1.; $8 \mathrm{Jul}$. 2011; F. Massariol and K.B. Angeli leg.; white sheet with an LED light; INPA • 10 ổ ô; Pará, Santarém, Florestal Nacional do Tapajós, Igarapé da Gica; 03¹5'38.7" S, 5456'42.8” W; 63 m a.s.1.; 18-25 Sep.

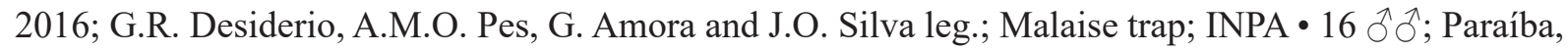
Mamanguape, Reserva Biológica Guaribas, Rio Barro Branco, ox head house; 06 43'7.3" S, 35¹0'55" W; 25 Jul. 2014; A.P.M. Santos, D.M. Takiya, A.C. Domahovski and W.R.M. Souza leg.; Pennsylvania trap; DZRJ • 3 đิ ô; Pernambuco, Igarassu, Refúgio Ecológico Charles Darwin; 0749'42" S, 3452'26" W; 4 m a.s.1.; 18 Nov. 2017; R. Pereira-Silva leg.; UFBA • 1 §; Tocantins, Palmas, Parque Estadual do Lajeado, Igarapé da Onça; $10^{\circ} 06^{\prime} 44.50^{\prime \prime}$ S, 48¹5'31.10" W; 596 m a.s.1.; 6-11 May 2017; N. Hamada and G. Amora leg.; Malaise trap; INPA.

\section{Distribution (Fig. 15B)}

Brazil: Amazon (Amazonas [new record], Pará [new record], Roraima [Albino et al. 2011]), Atlantic Forest (Alagoas [new record], Bahia [new record], Espírito Santo [new record], Paraíba [new record], Pernambuco [new record]), Caatinga (Ceará, Piaú [Takiya et al. 2016]), Cerrado (Distrito Federal [new record], Minas Gerais [Blahnik et al. 2004], São Paulo [Calor 2011], Tocantins [new record]), Bolivia, Colombia, Costa Rica, Ecuador, El Salvador, Guatemala, Honduras, Mexico, Nicaragua, Panama, Peru, Suriname, Tobago, Trinidad, Venezuela.

\section{Remarks}

This species is widely distributed in Central America and some countries in northern South America (Colombia, Peru, Suriname, Venezuela) (Fig. 15B) (Holzenthal \& Calor 2017). In Brazil, S. bivittata has been recorded only from the Cerrado biome in the states of Minas Gerais and São Paulo (Southeast region), and the Amazon biome in the state of Pará (North region) (Santos et al. 2020a). Nevertheless, this species was incorrectly recorded from the state of Pará by Paprocki et al. (2004) in their checklist of Brazilian Trichoptera because Paprocki's work was based on data from the literature and until then no previous study had reported the occurrence of S. bivittata from either the state of Pará or Brazil. This species was recorded in Brazil for the first time by Blahnik et al. (2004), from the state of Minas Gerais. Thus, this study provides the first record of S. bivittata from the Amazon biome in the state of Pará, based on specimens collected in a small stream located in the Floresta Nacional do Tapajós, a protected Amazon forest area.

The range of S. bivittata is extended in the Cerrado to the Distrito Federal and the state of Tocantins, and in the Amazon biome to the state of Amazonas. In addition, this study provides the first records of this species in the Atlantic Forest biome in the states of Alagoas, Bahia, Espírito Santo, Paraíba, and Pernambuco (Fig. 15B).

\section{Smicridea (Smicridea) erecta Flint, 1974}

Fig. 16A

Smicridea erecta Flint, 1974b: 87 (type locality: Suriname, Nassau Mountains, Km 11.3, creek; RNH; ð)). Smicridea erecta - Oláh \& Johanson 2012: 252 (distribution). - Holzenthal \& Calor 2017: 169 (catalog). —Alves et al. 2018: 394 (distribution). 


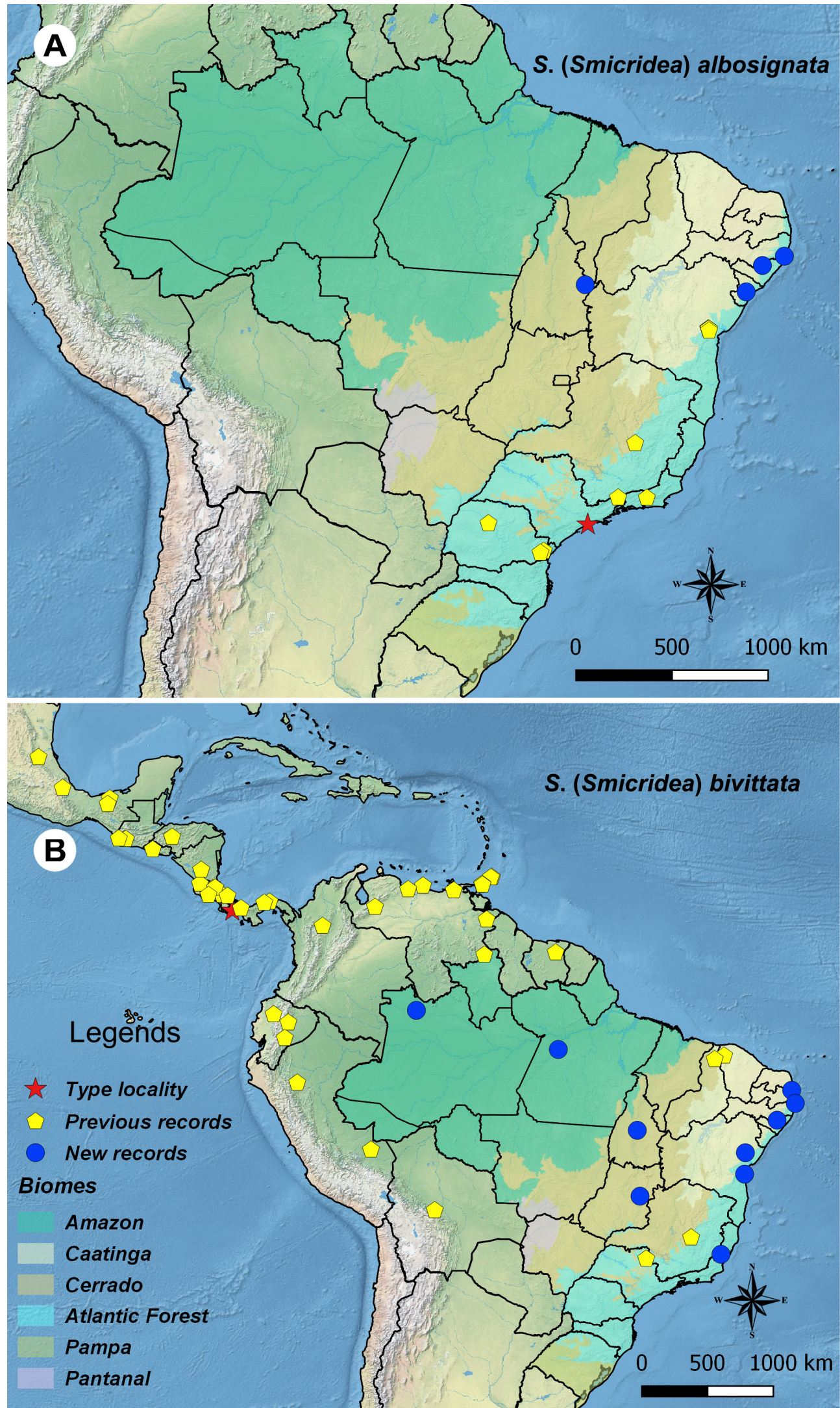

Fig. 15. Geographical distribution maps. A. Distribution of Smicridea (Smicridea) albosignata Ulmer, 1907. B. Distribution of Smicridea (Smicridea) bivittata (Hagen, 1861). 


\section{Material examined}

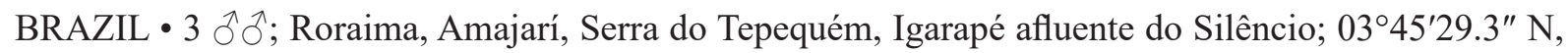
6145'29.3" W; 532 m a.s.1.; 11 Jul. 2016; A.M.O. Pes, G. Amora, G.P. Dantas and J.O. Silva leg.; Malaise

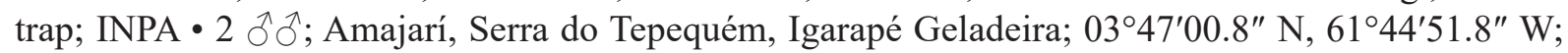
549 m a.s.1.; 8-11 Jul. 2016; A.M.O. Pes, G. Amora, G.P. Dantas and J.O. Silva leg.; Malaise trap; INPA

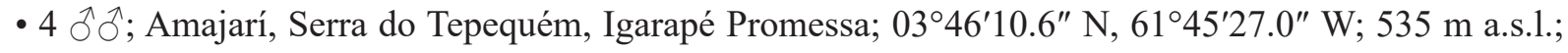
11 Jul. 2016; A.M.O. Pes, G. Amora, G.P. Dantas and J.O. Silva leg.; Malaise trap; INPA.

Distribution (Fig. 16A)

Brazil: Amazon (Amazonas [Alves et al. 2018], Roraima [new record]), French Guiana, Suriname.

\section{Smicridea (Smicridea) obliqua Flint, 1974}

Fig. 16B

Smicridea obliqua Flint, 1974b: 90 (type locality: Suriname, Kaboeri Creek, first camp, near Winnana creek; RNH; ふ).

Smicridea obliqua - Flint 1978: 398 (distribution). — Paprocki et al. 2004: 10 (checklist). — Albino et al. 2011: 25 (larva; pupa; biology; distribution). — Paprocki \& França 2014: 37 (checklist). — Desiderio et al. 2017: 162 (distribution). — Holzenthal \& Calor 2017: 178 (catalog). — Gibon \& Sganga 2019: 189 (distribution).

\section{Material examined}

BRAZIL - 1 đ; Acre, Senador Guiomard, Fazenda Experimental Catuaba (UFAC), Igarapé Floresta;

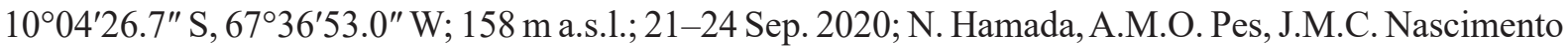
and J.O. Silva leg.; Pennsylvania trap; INPA • 1 đ̃; Amapá, Oiapoque, Igarapé do Aeroporto da FAB; 04 $10^{\prime} 06.20^{\prime \prime}$ N, 51 ${ }^{\circ} 47^{\prime} 31.0^{\prime \prime}$ W; 8 Aug. 2011; A.M.O. Pes, P.V. Cruz, A. Fernandes and N. Hamada leg.; white sheet with an LED light; INPA • $6 \partial^{\wedge}$; Oiapoque, Rio Oiapoque, Cachoeira Alta; $03^{\circ} 48^{\prime} 13.0^{\prime \prime} \mathrm{N}$, 51 ${ }^{\circ} 52^{\prime} 31.2^{\prime \prime}$ W; 13 m a.s.1.; 9 Aug. 2011; A.M.O. Pes, P.V. Cruz, A. Fernandes and N. Hamada leg.; white sheet with an LED light; INPA 10 đo ; Pedra Branca do Amapari, Igarapé da BR-210 near Pedra Branca; $00^{\circ} 37^{\prime} 38.00^{\prime \prime}$ N, 51 ${ }^{\circ} 38^{\prime} 15.20^{\prime \prime}$ W; 3 Aug. 2011; A.M.O. Pes, P.V. Cruz and A. Fernandes leg.; white sheet with an LED light; INPA 1 ' ${ }^{*}$; Mato Grosso, Sapezal, MT-235, Rio Papagaio, antes

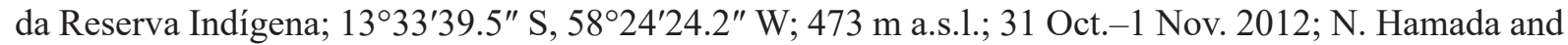
J.M.C. Nascimento leg.; Pennsylvania trap; INPA 1 đ ; Pará, Santarém, Floresta Nacional do Tapajós, BR-163, Km 108, Igarapé Jatuarana; 0315'44.7" S, 5457'22.0" W; 97 m a.s.1.; 15-24 Sep. 2016; G.R. Desiderio, A.M.O. Pes G. Amora and J.O. Silva leg.; Pennsylvania trap; INPA • 4 ô $\widehat{\jmath}$; Pará, Igarapé da

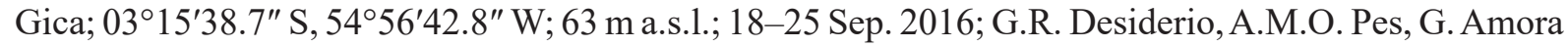
and J.O. Silva leg.; Malaise trap; INPA 11 ; Paraíba, Mamanguape, Reserva Biológica Guaribas, Rio

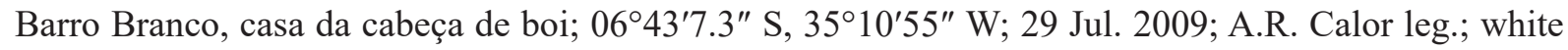

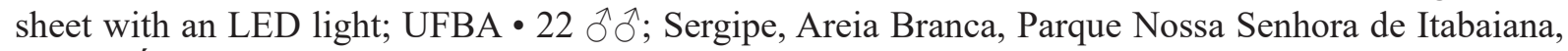
Riacho Água Fria; $10^{\circ} 45^{\prime} 16^{\prime \prime} \mathrm{S}, 37^{\circ} 20^{\prime} 32.5^{\prime \prime}$ W; 187 m a.s.l.; 5 Aug. 2009; A.R. Calor and L. Lecci leg.; UV light pan trap; UFBA - 1 đ̇; Itabaiana, Parque Nacional da Serra de Itabaiana, Riacho Água Fria; $10^{\circ} 45^{\prime} 17^{\prime \prime}$ S, 37²0'32.40" W; 196 m a.s.1.; 19 Jun. 2014; A.P.M. Santos, D.M. Takiya, A.C. Domahovski and W.R.M. Souza leg.; Pennsylvania trap; DZRJ.

\section{Distribution (Fig. 16B)}

Brazil: Amazon (Acre [new record], Amapá [new record], Amazonas [Flint 1978; Albino et al. 2011], Pará [new record]), Atlantic Forest (Paraíba [new record], Sergipe [new record]), Cerrado (Maranhão [Desiderio et al. 2017], Mato Grosso [new record]), French Guiane, Suriname. 

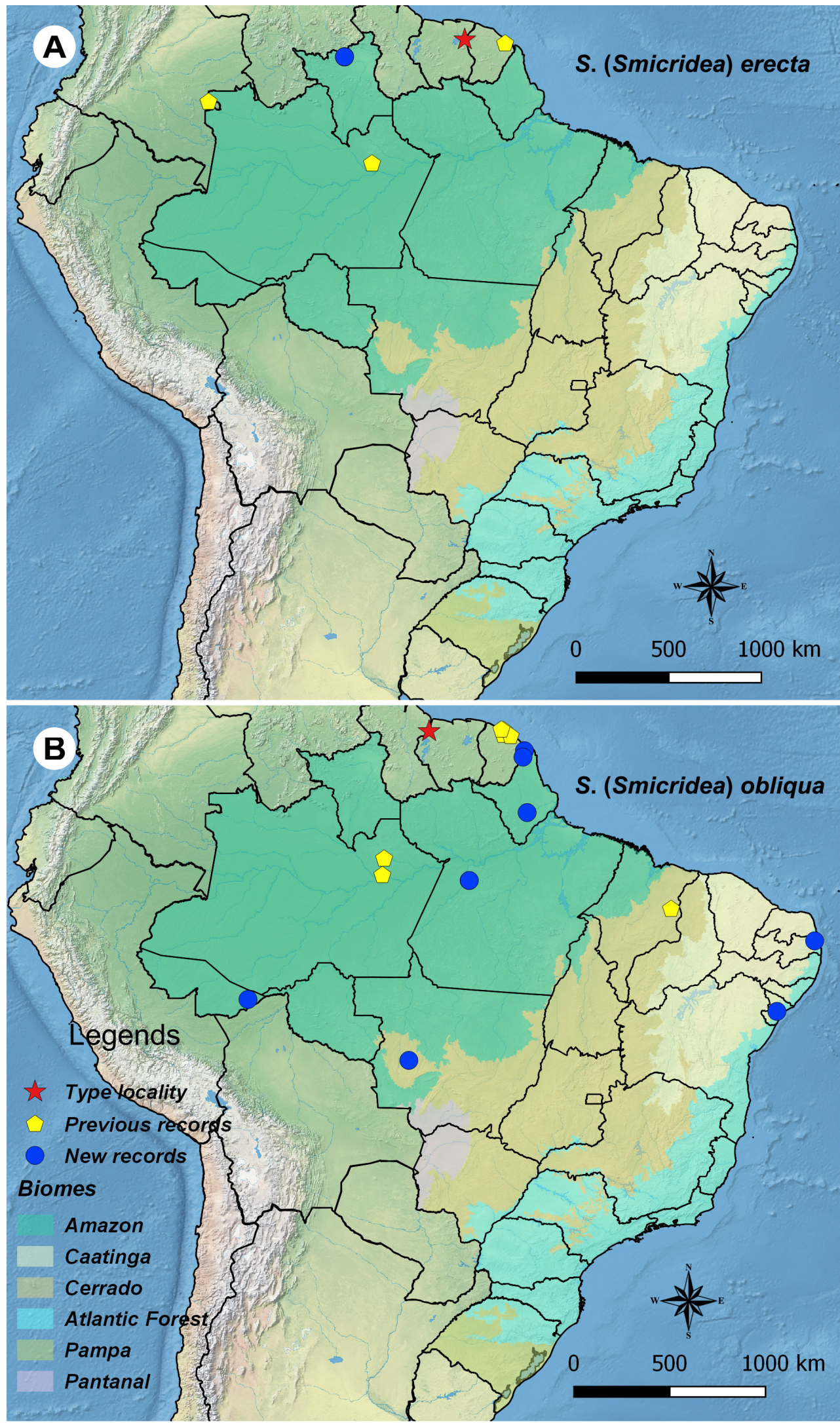

Fig. 16. Geographical distribution maps. A. Distribution of Smicridea (Smicridea) erecta Flint,1974. B. Distribution of Smicridea (Smicridea) obliqua Flint, 1974. 
Smicridea (Smicridea) paranensis Flint, 1983

Fig. 17A

Smicridea paranensis Flint, 1983: 55 (type locality: Argentina, Pcia. Misiones, 7 km E of El Dorado; $\mathrm{NMNH} ;$ ঐ).

Smicridea paranensis - Marinoni \& Almeida 2000: 286 (distribution; biology). - Blahnik et al. 2004: 4 (distribution). - Paprocki et al. 2004: 10 (checklist). — Sganga 2005: 142 (distribution). Dumas et al. 2009: 360 (distribution). — Calor 2011: 321 (checklist). — Paprocki \& França 2014: 38 (checklist). - Holzenthal \& Calor 2017: 179 (catalog). — Alves et al. 2018: 393 (distribution).

\section{Material examined}

BRAZIL - Distrito Federal • 1 đ̊; Brasília, Estação Ecológica de Águas Emendadas, Córrego Brejinho; 15³5'33.3" S, 47³8'14.4" W; 983 m a.s.1.; 4 Apr.-24 May 2018; G.R. Desiderio, C.A. Campos and F.R.B. Camelo leg.; Malaise trap; INPA • 22 సో; Estação Ecológica de Águas Emendadas, Córrego Tabatinga; 15³2'43.3" S, 47³3'58.4" W; 1047 m a.s.1.; 4-24 Apr. 2018; G.R. Desiderio, C.A. Campos

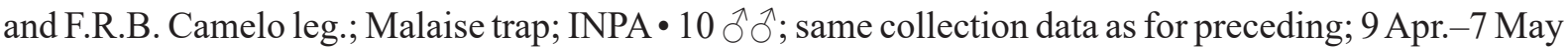
2018; INPA • 2 đ̂̉; Estação Ecológica de Águas Emendadas, Córrego Vereda Grande I; 15³2'33.0" S, 47³4'42.1" W; 1008 m a.s.1.; 4 Apr.-7 May 2018; G.R. Desiderio, C.A. Campos and F.R.B. Camelo leg.; Malaise trap; INPA • $2{ }^{\lambda}{ }^{\lambda}$; Brasília, Fazenda Água Limpa, Córrego Bonito; $15^{\circ} 57^{\prime} 17.7^{\prime \prime} \mathrm{S}, 47^{\circ} 57^{\prime} 46.0^{\prime \prime} \mathrm{W}$; 1071 m a.s.1.; 17-19 Jul. 2017; N. Hamada, G.R. Desiderio and G. Amora leg.; Pennsylvania trap; INPA

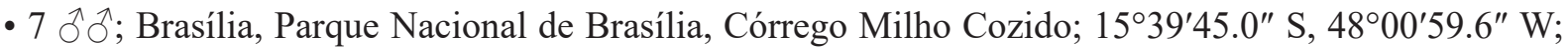
1076 m a.s.1.; 9 Apr.-4 Aug. 2018; G.R. Desiderio, C.A. Campos and F.R.B. Camelo legs.; Malaise trap;

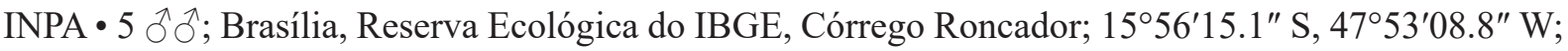
1064 m a.s.l.; 3 Apr.-15 Jun. 2018; G.R. Desiderio, C.A. Campos and F.R.B. Camelo leg.; Malaise trap;

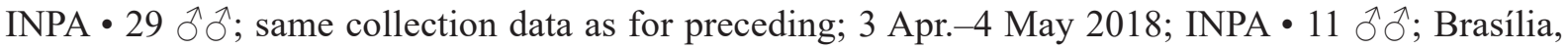
Reserva Ecológica Jardim Botânico, Córrego Cabeça de Veado I; 1553'23.7" S, 4750'33.0" W; 1119 m a.s.1.; 2 Apr.-15 May 2018; G.R. Desiderio, C.A. Campos and F.R.B. Camelo leg.; Malaise trap; INPA

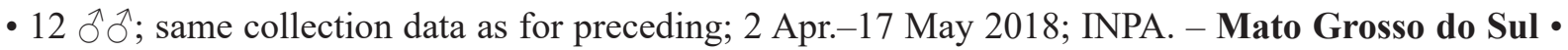
$1 \partial^{\prime}$; Bodoquena, Estrada para a boca da onça; 2045'13.8" S, 56²39'50.9" W; 10 Sep. 2013; D.M. Takiya

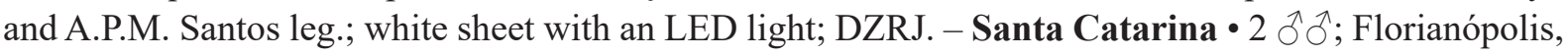
Córrego Pantanal; 27³6'35" S, 48³0'57" W; 13 Jul. 2012; L.C. Pinho leg.; entomological net; UFBA. - Tocantins • 7 ठิ ô; Palmas, Parque Estadual do Lajeado, Igarapé Brejo da Besta; 1003'55.90" S, 48 14'57.70" W; 469 m a.s.1.; 6-14 Jun. 2016; A.M.O. Pes, G. Amora and J.O. Silva leg.; Pennsylvania trap; INPA • 1 đ’; Parque Estadual do Lajeado, Igarapé da Onça; $10^{\circ} 06^{\prime} 44.50^{\prime \prime} \mathrm{S}, 48^{\circ} 15^{\prime} 31.10^{\prime \prime} \mathrm{W} ; 596 \mathrm{~m}$ a.s.1.; 6-11 May 2017; N. Hamada, G. Amora leg.; Malaise trap; INPA • 1 ऽे; Parque Estadual do Lajeado, Igarapé Brejo da Lagoa Seca; 1004'25.00" S, 48¹3'29.10" W; 447 m a.s.1.; 2-10 Jun. 2016; A.M.O. Pes, G. Amora and J.O. Silva leg.; Pennsylvania trap; INPA • 1 đ; Parque Estadual do Lajeado, Igarapé da Maritaca; $10^{\circ} 03^{\prime} 33.60^{\prime \prime}$ S, 48 $13^{\prime} 34.30^{\prime \prime}$ W; 597 m a.s.1.; 5-10 Jun. 2016; A.M.O. Pes, G. Amora and J.O. Silva leg.; Malaise trap; INPA • 2 ô ô; Parque Estadual do Lajeado, Igarapé do Saltim; $10^{\circ} 03^{\prime} 33.40^{\prime \prime}$ S, 48 13'49.30" W; 581 m a.s.1.; 5-10 Jun. 2016; A.M.O. Pes, G. Amora and J.O. Silva leg.; Malaise trap; INPA.

\section{Distribution (Fig. 17A)}

Argentina, Brazil: Caatinga (Ceará, Piauí [Alves et al. 2018]), Cerrado (Distrito Federal [new record], Mato Grosso do Sul [new record], Tocantins [new record]), Atlantic Forest (Minas Gerais [Blahnik et al. 2004], Paraná [Marinoni \& Almeida 2000], Rio de Janeiro [Blahnik et al. 2004; Dumas et al. 2009], São Paulo [Calor 2011], Santa Catarina [new record]), Paraguay. 
Smicridea (Smicridea) sattleri Denning \& Sykora, 1968

Fig. 17B

Smicridea sattleri Denning \& Sykora, 1968: 175 (type locality: Brazil, Sao Paulo, waterfall on Iporanga

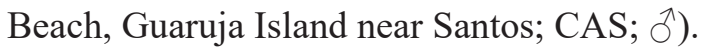

Smicridea sattleri - Paprocki et al. 2004: 10 (checklist). - Calor 2011: 321 (checklist). — Paprocki \& França 2014: 38 (checklist). — Rocha et al. 2016: 429 (distribution). — Holzenthal \& Calor 2017: 182 (catalog).

\section{Material examined}

BRAZIL - Bahia • 1 đ’; Camacan, Reserva Particular do Patrimônio Natural Serra Bonita; $15^{\circ} 22^{\prime} 59.1^{\prime \prime}$ S,

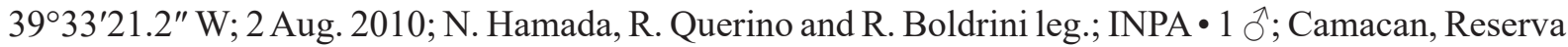
Particular do Patrimônio Natural Serra Bonita, Córrego Fechadinho; 15²3'9.1" S, 39³3'21.2" W; 27 Nov. 2011; A.R. Calor leg.; UV light pan trap; UFBA 5 万人 $\widehat{\lambda}$; Wesceslau Guimarães, E.E.E.W.G. Riacho Serra Grande, Cachoeira; 13³5'35.4" S, 3942'51.2" W; 513 m a.s.1.; 6 Sep. 2013; A.R. Calor, T. Duarte and E.S. Dias leg.; entomological net; UFBA • 1 ${ }^{\lambda}$; same collection data as for preceding; 7 Sep. 2013; UV light pan trap; UFBA 2 ○ึ; same collection data as for preceding; 8 Sep. 2013; UFBA- Espírito Santo

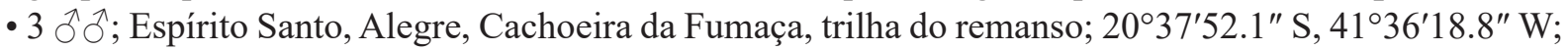
27 May 2011; J.M.C. Nascimento, P. Barcelos-Silva, K. Angeli and K. Bertazo leg.; white sheet with an

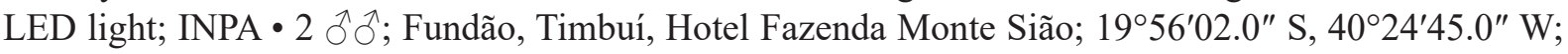
57 m a.s.1.; Sep. 2014; P. Barcelos-Silva leg.; Malaise trap; INPA 1 ơ; Santa Leopoldina, Rio da Prata, acima da cachoeira Véu da Noiva; 2002'49.7" S, 40³1'55.9" W; 487 m a.s.1.; 3 Apr. 2011; L.L. Dumas

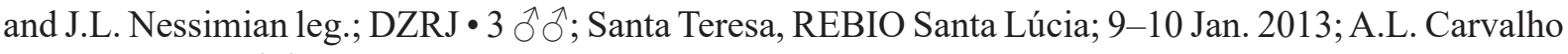
leg.; DZRJ • 6 đ̊̊; Santa Teresa, REBIO Santa Lúcia, Córrego Bonito, acima da Cachoeira Heloísa Torres; 1958'25.9" S, 40³1'46.3" W; 695 m a.s.1.; 3 Apr. 2011; L.L. Dumas and G.A. Jardim leg.; DZRJ.

\section{Distribution (Fig. 17B)}

Brazil: Atlantic Forest (Bahia [new record], Espírito Santo [new record], São Paulo [Denning \& Sykora 1968]), Cerrado (Minas Gerais [Rocha et al. 2016]).

\section{Discussion}

Although Smicridea is highly diverse and widely distributed in Brazil, its geographic distribution is poorly known, and its diversity may be underestimated because some Brazilian states, regions, and biomes have not been sampled yet. Some recent contributions have been made to reduce the biodiversity shortfalls regarding the Brazilian Smicridea fauna (Rocha et al. 2016; Alves et al. 2018; Vilarino et al. 2019; Desiderio et al. 2020, 2021). In this paper, we describe six new species of $S$. (Smicridea), significantly increasing the number of species of this subgenus in Brazil from 21 to 27. We also provide the first records of the genus Smicridea for the Brazilian states of Acre, Amapá, and Sergipe; and of S. (Smicridea) for the states of Rio Grande do Sul and Santa Catarina. The records of S. jeaneae sp. nov. in Amapá State and S. caaguara sp. nov. in Rio Grande do Sul State are the northernmost and southernmost records of the genus in Brazil, respectively.

Genital structures have been remarkably useful for differentiating species in the S. fasciatella group treated here. The number, type, and position of the setae and the shape of the apex of tergum X are the most useful characters. Additionally, the number of stout apical spine-like setae on the basal segment of the inferior appendage and the shape of the apical segment, which has acuminate setae or thin setae on its apex, are useful characters to discriminate species in this group. The shape of the phallotremal sclerite of the phallus (especially as viewed dorsally), used by Flint (1974a) to differentiate species in 

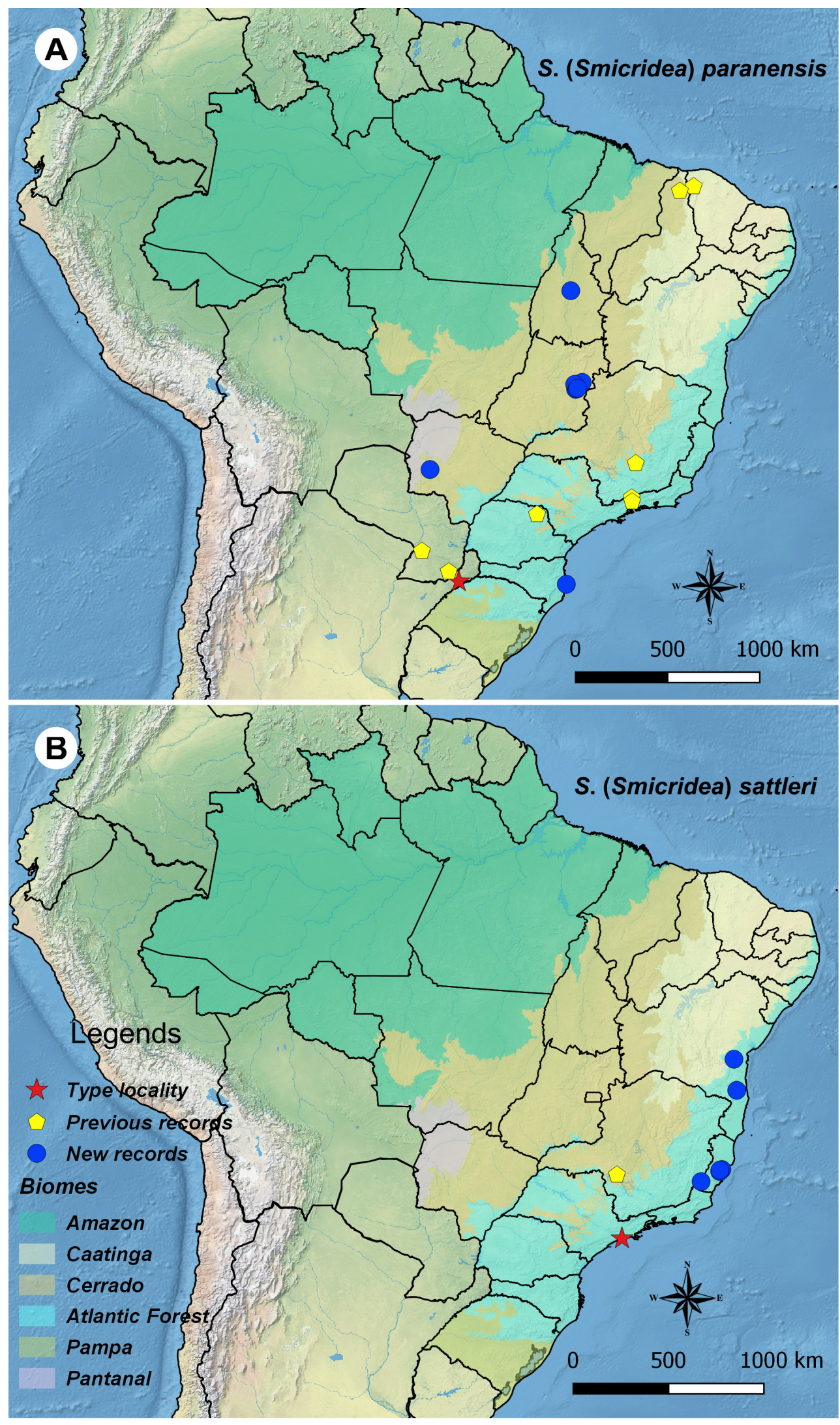

Fig. 17. Geographical distribution maps. A. Distribution of Smicridea (Smicridea) paranensis Flint, 1983. B. Distribution of Smicridea (Smicridea) sattleri Denning \& Sykora, 1968. 
S. fasciatella group from North and Central America, also proved to be a useful character for diagnosing Brazilian species in this group. Even though the shape of the phallotremal sclerite has not been useful for separating species in the S. fasciatella complex (Blahnik 1995), we believe that this is one of the most important diagnostic characters for identifying species in the fasciatella species group as a whole.

In this study, some new species do not present diagnostic characters that would allow us to place them in one of the two currently recognized species subgroups (albosignata and fasciatella). However, we note that they share characters that are unusual within the $S$. fasciatella group, such as a distinct apicomesal lobe on each tergite X in S. blahniki sp. nov., S. erecta, and S. jeaneae sp. nov., and the presence of endothecal spines in $S$. paranensis and S. polyacantha sp. nov. These shared characteristics may be an indication of the existence of a new subgroup within the $S$. fasciatella group.

Curiously, the reticulate sacs are absent in $S$. brevitruncata sp. nov. This fact is unique within the subgenus Smicridea. In S. patinae Pauls, Blahnik \& Holzenthal, 2010 and S. microsaccata Flint, 1991 from Chile and Colombia, respectively, only a pair of reduced internal glands are present in segment VII. The internal glands in abdominal segments VI and VII seem to be a plesiomorphic character in S. (Smicridea), as they also occur in the closely related Smicrideinae genus Smicrophylax Neboiss, 1977, and in the Diplectroninae genera Austropsyche Banks, 1939, Arcyphysa Wells \& Neboiss, 2018, and Diplectrona Westwood, 1839 (Neboiss 1977; Wells \& Neboiss 2018).

Because $S$. (Smicridea) groups or subgroups have never been treated under a cladistic approach, a phylogenetic study would be very relevant to evaluate how these characters are related to each other. This is needed to delimit the already-proposed taxonomic subgroups (e.g., albosignata, fasciatella complexes) and to establish any potentially new subgroups. Nevertheless, this is outside of the scope of this paper because we only focused on the description of new species and the distribution of Brazilian species in the S. fasciatella group.

This study highlights the need for more taxonomic studies focused on S. (Smicridea) in Brazil in general, especially in the poorly sampled Caatinga, Pampas, and Pantanal biomes. The S. (Smicridea) species seem to prefer small to medium-sized streams based on the bionomic data for the new species and the collection data on the known species that are treated here. Future collections should therefore be directed to poorly sampled environments. Additionally, there are many undescribed species deposited in different entomological collections worldwide (Santos et al. 2020b). Therefore, more taxonomists are needed to make all of this unknown diversity available.

\section{Acknowledgments}

We are grateful to the editor, Dr Helen M. Barber-James, for her assistance and we highly appreciate the very useful suggestions of the two anonymous reviewers to improve the manuscript. We thank all of our colleagues who collected and provided material for this study, especially Jeferson O. da Silva for fieldwork support and Marcos Silva (Oiapoque) for collecting the type specimen of $S$. jeaneae sp. nov. We thank the Instituto Chico Mendes de Conservação da Biodiversidade (ICMBio) for collecting permits (59800-1), and Parque Estadual Lajeado (TO) managers and José de Ribamar Santos for the maintenance of Malaise traps in the field. Dr Cesar Benetti and Jeferson O. da Silva provided some of the habitat photos. GRD is grateful to Dr Beatriz Ronchi Teles (INPA) for allowing use of the laboratory infrastructure. This study was financed in part by the Coordenação de Aperfeiçoamento de Pessoal de Nível Superior - Brasil (CAPES) - finance code 001; Fundação de Amparo à Pesquisa do Estado do Amazonas (FAPEAM) POSGRAD 2019; Sistemática integrada de insetos aquáticos, com ênfase em Simuliidae (Diptera) na América do Sul (MCTIC/INPA); Insetos aquáticos fragmentadores e fungos associados: taxonomia, interação e potencial de uso biotecnológico-Edital BIONORTE (407843/2013-2). GRD is grateful to Dr Adolfo Calor (UFBA), Dr Allan Santos (UNIRIO), Dr Daniela Takiya (UFRJ) and Dr Jorge Nessimian 
(UFRJ) for their assistance and the loan of valuable specimens deposited in their collections. We thank Marcos Silveira and Martin Acosta Oliveira (UFAC) for assistance in obtaining collecting licenses and for help in the fieldwork in the PPBio grid in Acre state. We also thank the Invertebrate Collection of INPA for allowing the use of photographic equipment. Conselho Nacional de Desenvolvimento Científico e Tecnológico (CNPq) provided a doctoral fellowship for GRD (141875/2018-442 6) and a research fellowship for NH (307849/2014-7; 308970/ 2019-5). AMP received post-doctoral fellowships from PCI/INPA (301401/2019-5) and PDS/CNPq (165223/2017-0). We are grateful to Philip M. Fearnside for revising an earlier version of this manuscript.

\section{References}

Aguila Y. 1992. Systematic catalogue of the caddisflies of Panama (Trichoptera). In: Quintero D. \& Aiello A. (eds) Insects of Panama and Mesoamerica: Selected Studies: 532-548. Oxford University Press, Oxford.

Albino J.L.D., Pes A.M. \& Hamada N. 2011. Smicridea (Trichoptera, Hydropsychidae) from 3 Brazilian Amazonian States: New species, larval taxonomy and bionomics. Zootaxa 3113: 1-35.

Alves A.A., Santos A.P.M. \& Nessimian J.L. 2018. A new species of Smicridea McLachlan 1871 (Trichoptera: Hydropsychidae) from the Caatinga biome and new distributional records from Brazil. Zootaxa 4500 (3): 388-396. https://doi.org/10.11646/zootaxa.4500.3.6

Armitage B.J. \& Cornejo A. 2015. Orden Trichoptera (Insecta) en Panamá: Listas de especies y su distribución por cuencas y unidades administrativas. Puente Biológico 7: 175-199.

Armitage B.J., Harris S.C., Arefina-Armitage T.I. \& Corne A. 2015. The Trichoptera of Panama. III. Updated species list for caddisflies (Insecta: Trichoptera) in the Republic of Panama. Insecta Mundi 0442: $1-16$.

Banks N. 1920. New neuropteroid insects. Bulletin of the Museum of Comparative Zoology 64: 297-362. https://doi.org/10.5962/bhl.title.28705

Blahnik R.J. 1995. New species of Smicridea (subgenus Smicridea) from Costa Rica, with a revision of the fasciatella complex (Trichoptera: Hydropsychidae). Journal of the North American Benthological Society 14 (1): 84-107. https://doi.org/10.2307/1467726

Blahnik R.J. \& Holzenthal R.W. 2004. Collection and curation of Trichoptera, with an emphasis on pinned material. Nectopsyche, Neotropical Trichoptera Newsletter 1: 8-20.

Blahnik R.J., Paprocki H. \& Holzenthal R.W. 2004. New distribution and species records of Trichoptera from southern and southeastern Brazil. Biota Neotropica 4: 1-6.

https://doi.org/10.1590/S1676-06032004000100009

Blahnik R.J., Holzenthal R.W. \& Prather A.L. 2007. The lactic acid method for clearing Trichoptera genitalia. In: Bueno-Soria J., Barba-Alvarez R. \& Armitage B.J. (eds) Proceedings of the $12^{\text {th }}$ International Symposium on Trichoptera: 9-14. The Caddis Press, Columbus, Ohio.

Botosaneanu L. 1989. Notes on the caddisflies (Insecta, Trichoptera) from Isla Margarita (Venezuela). Amsterdam expeditions to the West Indian Islands, no. 56. Bulletin Zoölogisch Museum, Universiteit van Amsterdam 11: 203-209.

Botosaneanu L. 2002. An annotated checklist of caddisflies from the Caribbean islands, with distribution and bibliography (Insecta, Trichoptera). Bulletin de la Société entomologique de France 107: 79-108.

Botosaneanu L. \& Alkins-Koo M. 1993. The caddis flies (Insecta: Trichoptera) of Trinidad and Tobago, West Indies. Bulletin de l'Institut royal des Sciences naturelles de Belgique, Entomologie 63: 5-45.

Botosaneanu L. \& Sakal D. 1992. Ecological observations on the caddisflies (Insecta: Trichoptera) from Trinidad and Tobago (W. Indies). Revue d'Hydrobiologie tropicale 25: 197-207. 
Botosaneanu L. \& Viloria A.L. 2002. The caddisflies (Insecta, Trichoptera) of Isla de Margarita (Venezuela) - with description of two new species. Deutsche entomologische Zeitschrift 49: 105-111. https://doi.org/10.1002/mmnd.20020490108

Brown J.H. \& Lomolino M.V. 1998. Biogeography. Sinauer, Sunderland.

Brown V.B. 2013. Automating the "Material Examined" section of taxonomy papers to speed up species descriptions. Zootaxa 3683 (3): 297-299. https://doi.org/10.11646/zootaxa.3683.3.8

Bueno-Soria J. \& Barba-Álvarez R. 2011. Trichoptera de Chiapas. In: Álvarez F. (ed.) Chiapas: Estudios sobre su Diversidad biológica: 345-362. Universidad Nacional Autónoma de México, Mexico City.

Bueno-Soria J. \& Flint O.S. Jr 1978. Catálogo sistemático de los tricopteros de México (Insecta: Trichoptera), con algunos registros de Norte, Centro y Sudamérica. Anales del Instituto de Biología, Universidad Nacional Autónoma de México, Serie Zoología 49: 189-218.

Bueno-Soria J., Morrone J.J. \& Barba-Alvarez R. 2005. Trichoptera of Arroyo Las Flores, Tabasco, Mexico, and their biogeographic affinities. In: Tanida K. \& Rossiter A. (eds) Proceedings of the $11^{\text {th }}$ International Symposium on Trichoptera: 73-76. Tokai University Press, Kanagawa.

Calor A.R. 2011. Checklist of Trichoptera (Insecta) from São Paulo State, Brazil. Biota Neotropica 11: 317-328. https://doi.org/10.1590/S1676-06032011000500028

Calor A.R. \& Mariano R. 2012. UV light pan traps for collecting aquatic insects. Entomobrasilis 5 (2): 164-166. https://doi.org/10.12741/ebrasilis.v5i2.187

Chamorro-Lacayo M.L., Maes J.M., Holzenthal R.W. \& Blahnik R.J. 2007. Updated checklist of the Trichoptera of Nicaragua. In: Bueno-Soria J., Barba-Álvarez R. \& Armitage B.J. (eds) Proceedings of the $12^{\text {th }}$ International Symposium on Trichoptera: 37-50. The Caddis Press, Columbus, Ohio.

Dallwitz M.J., Paine T.A. \& Zurcher E.J. 1999. User's guide to the DELTA editor. Available from http://delta-intkey.com [accessed 23 May 2016].

Denning D.G. \& Sykora J.L. 1968. Three new species of Trichoptera from Brazil. Beiträge zur neotropischen Fauna 5: 172-177. https://doi.org/10.1080/01650526809360405

Desiderio G.R., Barcelos-Silva P., Souza W.R.M., Pes A.M. \& Azevedo C.A.S. 2017. Caddisflies (Insecta: Trichoptera) from Maranhão State, Northeast Region, Brazil: a new species, checklist, and new geographical records. Zootaxa 4221 (2): 151-171. https://doi.org/10.11646/zootaxa.4221.2.1

Desiderio G.R., Rázuri-Gonzales E., Pes A.M. \& Hamada N. 2020. Smicridea (Smicridea) nigripennis species group (Trichoptera: Hydropsychidae) from Brazil: new species, new distributional records and an identification key. Austral Entomology 59: 265-279. https://doi.org/10.1111/aen.12459

Desiderio G.R., Santana V., Pereira E.S., Pes A.M. \& Hamada N. 2021. On the identity of Smicridea (Smicridea) aequalis Banks, 1920 (Trichoptera: Hydropsychidae): morphology of adults and immature stages, bionomics, distribution, and male color dimorphism. Neotropical Entomology 50: 430-443.

https://doi.org/10.1007/s13744-021-00860-8

Dumas L.L. \& Nessimian J.L. 2012. Faunistic catalog of the caddisflies (Insecta: Trichoptera) of Parque Nacional do Itatiaia and its surroundings in southeastern Brazil. Journal of Insect Science 12: 1-38. https://doi.org/10.1673/031.012.2501

Dumas L.L., Jardim G.A., Santos A.P.M. \& Nessimian J.L. 2009. Tricópteros (Insecta: Trichoptera) do estado do Rio de Janeiro: Lista de espécies e novos registros. Arquivos do Museu Nacional, Rio de Janeiro 67: 355-376.

Flint O.S. Jr 1967. Studies of Neotropical caddis flies, V: types of the species described by Banks and Hagen. Proceedings of the United States National Museum 123: 1-37.

https://doi.org/10.5479/si.00963801.123-3619.1 
Flint O.S. Jr 1974a. Studies of Neotropical caddisflies, XVII: the genus Smicridea from North and Central America (Trichoptera: Hydropsychidae). Smithsonian Contributions to Zoology 167: 1-65. https://doi.org/10.5479/si.00810282.167

Flint O.S. Jr 1974b. The Trichoptera of Surinam. Studies of Neotropical caddisflies, XV. Studies on the Fauna of Suriname and other Guyanas 14: 1-151.

Flint O.S. Jr 1978. Studies of Neotropical Caddisflies, XXII: Hydropsychidae of the Amazon Basin (Trichoptera). Amazoniana 6: 373-421.

Flint O.S. Jr 1981. Studies of Neotropical caddisflies, XXVIII: The Trichoptera of the Río Limón Basin, Venezuela. Smithsonian Contributions to Zoology 330: 1-61. https://doi.org/10.5479/si.00810282.330

Flint O.S. Jr 1983. Studies of Neotropical caddisflies, XXXIII: new species from austral South America (Trichoptera). Smithsonian Contributions to Zoology 377: 1-100.

https://doi.org/10.5479/si.00810282.377

Flint O.S. Jr 1989. Studies of Neotropical caddisflies, XXXIX: the genus Smicridea in the Chilean subregion (Trichoptera: Hydropsychidae). Smithsonian Contributions to Zoology 472: 1-45.

https://doi.org/10.5479/si.00810282.472

Flint O.S. Jr 1991. Studies of Neotropical caddisflies, XLV: The taxonomy, phenology, and faunistics of the Trichoptera of Antioquia, Colombia. Smithsonian Contributions to Zoology 520: 1-113.

https://doi.org/10.5479/si.00810282.520

Flint O.S. Jr 1996. Studies of Neotropical caddisflies LV: Trichoptera of Trinidad and Tobago. Transactions of the American Entomological Society 122: 67-113.

Flint O.S. Jr \& Reyes L. 1991. Studies of Neotropical caddisflies, XLVI: the Trichoptera of the Río Moche Basin, Department of La Libertad, Peru. Proceedings of the Biological Society of Washington 104: 474-492.

Frost S.W. 1957. The Pennsylvania insect light trap. Journal of Economic Entomology 9: 52-172.

https://doi.org/10.1093/jee/50.3.287

GBIF. 2020. GBIF Occurrence Download. Available from https://www.gbif.org/ [accessed 10 Aug. 2020].

Gibon F.M. \& Sganga J.V. 2019. The genera Smicridea McLachlan and Chimarra Stephens in French Guiana (Trichoptera: Hydropsychidae, Philopotamidae). Zootaxa 4604 (1): 183-190.

https://doi.org/10.11646/zootaxa.4604.1.8

Gressitt J.L. \& Gressitt M.K. 1962. An improved Malaise trap. Pacific Insects 4: 87-90.

Hagen H.A. 1861. Synopsis of the Neuroptera of North America with a list of the South American species. Smithsonian Institution Miscellaneous Collections 4: 1-347.

https://doi.org/10.5962/bhl.title.60275

Holzenthal R.W. 1988. Catalogo systematico de los Trichopteros de Costa Rica (Insecta: Trichoptera). Brenesia 29: 51-82.

Holzenthal R.W. \& Calor A.R. 2017. Catalog of the Neotropical Trichoptera (caddisflies). ZooKeys 654: 1-566. https://doi.org/10.3897/zookeys.654.9516

IBGE. 2019. Biomas. Available from https://www.ibge.gov.br/geociencias/informacoes-ambientais/ [accessed 22 Jun. 2020].

Kawada R. \& Buffington M.L. 2016. A scalable and modular dome illumination system for scientific microphotography on a budget. PLoS ONE 11 (5): e 0153426.

https://doi.org/10.1371/journal.pone.0153426

Lomolino M.V. 2004. Conservation biogeography. In: Lomolino M.V. \& Heaney L.R. (eds) Frontiers of Biogeography: New Directions in the Geography of Nature: 293-96. Sinauer, Sunderland. 
Maes J.M. 1999. Orden Trichoptera. In: Maes J.M. (ed.) Insectos de Nicaragua, Catálogo de los Insectos y Artropodos Terrestres de Nicaragua Vol III: 1184-1199. Managua, Nicaragua.

Maes J.M. \& Flint O.S. Jr 1988. Catalogo de los Trichoptera de Nicaragua. Revista Nicaraguense de Entomologia 2: 1-11.

Marinoni L. \& Almeida G.L. 2000. Abundância e sazonalidade das espécies de Hydropsychidae (Insecta, Trichoptera) capturadas com armadilha luminosa no Estado do Paraná, Brasil. Revista Brasileira de Zoologia 17: 283-299. https://doi.org/10.1590/S0101-81752000000100025

McLachlan R. 1871. On new forms, etc., of extra-European Trichopterous insects. Journal of the Linnean Society of London, Zoology 11: 98-141. https://doi.org/10.1111/j.1096-3642.1870.tb02011.x

Mey W. \& Ospina-Torres R. 2018. Contribution to the Trichoptera fauna of the river La Vieja, Bogotá, Colombia (Insecta: Trichoptera). Zootaxa 4504 (1): 23-40. https://doi.org/10.11646/zootaxa.4504.1.2

Muñoz-Quesada F. 2000. Especies del orden Trichoptera (Insecta) en Colombia. Biota Colombiana 1: 267-288.

Natural Earth. 2020. Free vector and raster map data. Available from http://naturalearthdata.com/ [accessed 12 May 2020].

Navás L. 1924. Insectos de la América Central. Brotéria, Série Zoológica 21: 55-86.

Neboiss A. 1977. A taxonomic and zoogeographic study of Tasmanian caddis-flies (Insecta: Trichoptera). Memoirs of the National Museum of Victoria 38: 1-208. https://doi.org/10.24199/j.mmv.1977.38.01

Oláh J. \& Johanson K.A. 2012. New species and records of Neotropical Macronematinae and Smicrideinae (Trichoptera: Hydropsychidae). Annales Historico-Naturales Musei Nationalis Hungarici 104: 215-297.

Paprocki H. \& França D. 2014. Brazilian Trichoptera Checklist II. Biodiversity Data Journal 2: e1557. https://doi.org/10.3897/BDJ.2.e1557

Paprocki H., Holzenthal R.W. \& Blahnik R.J. 2004. Checklist of the Trichoptera (Insecta) of Brazil I. Biota Neotropica 4: 1-22. https://doi.org/10.1590/S1676-06032004000100008

Pes A.M.O. \& Santos A.P.M. 2020. Hydropsychidae in Catálogo Taxonômico da Fauna do Brasil. PNUD. Available from http://fauna.jbrj.gov.br/fauna/faunadobrasil/14819/ [accessed 14 Jul. 2020].

QGIS Development Team. 2016. QGIS geographic information system. Open Source Geospatial Foundation Project. Available from https://www.qgis.org [accessed 9 May 2020].

Rázuri-Gonzales E. \& Armitage B.J. 2019. The Trichoptera of Panama. XI. Three new species of caddisflies in the genus Smicridea McLachlan (Trichoptera: Hydropsychidae) from Omar Torrijos and Santa Fe National Parks. Insecta Mundi 0710: 1-13.

Rocha I.C., Dumas L.L. \& Nessimian J.L. 2016. Three new species and a new record of Smicridea McLachlan 1871 (Trichoptera: Hydropsychidae) from Minas Gerais state, Brazil. Zootaxa 4107 (3): 423-430. https://doi.org/10.11646/zootaxa.4107.3.10

Ross H.H. 1952. Lectotypes of Hagen species belonging to certain families of Trichoptera. Psyche 59: 31-36. https://doi.org/10.1155/1952/52847

Santos A.P.M., Dumas L.L., Henriques-Oliveira A.L., Souza W.R.M., Camargos L.M., Calor A.R. \& Pes A.M.O. 2020a. Trichoptera in Catálogo Taxonômico da Fauna do Brasil. PNUD. Available from http://fauna.jbrj.gov.br/fauna/faunadobrasil/278/ [accessed 20 Aug. 2020].

Santos A.P.M., Dumas L.L., Henriques-Oliveira A.L., Souza W.R.M., Camargos L.M., Calor A.R. \& Pes A.M.O. 2020b. Taxonomic Catalog of the Brazilian Fauna: Order Trichoptera (Insecta), diversity and distribution. Zoologia 37: e46392. https://doi.org/10.3897/zoologia.37.e46392

Sganga J.V. 2005. A new species of Smicridea from Argentina (Trichoptera: Hydropsychidae). Revista de la Sociedad entomológica Argentina 64: 141-145. 
Sganga J.V. \& Fontanarrosa M.S. 2006. Contribution to the knowledge of the preimaginal stages of the genus Smicridea McLachlan in South America (Trichoptera: Hydropsychidae: Smicrideinae). Zootaxa 1258: $1-15$.

Sganga J.V. \& Gibon F.M. 2018. New species, new records, and distribution of Smicridea McLachlan 1871 in Bolivia (Trichoptera: Hydropsychidae). Neotropical Entomology 48: 399-414. https://doi.org/10.1007/s13744-018-0645-0

Takiya D.M., Santos A.P.M., Pinto Â.P., Henriques-Oliveira A.L., Carvalho A.L., Sampaio B.H.L., Clarkson B., Moreira F.F.F., Avelino-Capistrano F., Gonçalves I.C., Cordeiro I.R.S., Câmara J.T., Barbosa J.F., Souza W.R.M. \& Rafael J. 2016. Aquatic insects from the Caatinga: checklists and diversity assessments of Ubajara (Ceará State) and Sete Cidades (Piauí State) National Parks, Northeastern Brazil. Biodiversity Data Journal 4: e8354. https://doi.org/10.3897/BDJ.4.e8354

Ulmer G. 1907. Neue Trichopteren. Notes from the Leyden Museum 29: 1-53.

Vilarino A. \& Calor A.R. 2017. Trichoptera of Serra da Jibóia, Bahia, Brazil: new species of Helicopsyche (Helicopsychidae) and new records. Zootaxa 4311 (4): 507-522.

https://doi.org/10.11646/zootaxa.4311.4.4

Vilarino A., Dias E.S. \& Calor A.R. 2019. New species and records of the most diverse caddisfly genus in Brazil, Smicridea McLachlan, 1871 (Trichoptera: Hydropsychidae): solving a species delimitation through an integrative taxonomic approach. Austral Entomology 58: 707-723.

https://doi.org/10.1111/aen.12417

Weidner H. 1964. Die entomologische Sammlungen des Zoologischen Staatsinstituts und Zoologischen Museums Hamburg. X. Teil, Insecta VII. Mitteilungen aus dem hamburgischen zoologischen Museum und Institut 62: 55-100.

Wells A. \& Neboiss A. 2018. Australian Diplectroninae reviewed (Insecta: Trichoptera), with description of 21 new species, most referred to a new genus. Zootaxa 4415 (1): 1-44.

https://doi.org/10.11646/zootaxa.4415.1.1

Wiggins G.B. 1996. Larvae of the North American Caddisfly Genera (Trichoptera). $2^{\text {nd }}$ Edition. University of Toronto Press, Toronto. https://doi.org/10.3138/9781442623606

Manuscript received: 7 December 2020

Manuscript accepted: 3 March 2021

Published on: 24 May 2021

Topic editor: Nesrine Akkari

Section editor: Helen M. Barber-James

Desk editor: Radka Rosenbaumová

Printed versions of all papers are also deposited in the libraries of the institutes that are members of the EJT consortium: Muséum national d'histoire naturelle, Paris, France; Meise Botanic Garden, Belgium; Royal Museum for Central Africa, Tervuren, Belgium; Royal Belgian Institute of Natural Sciences, Brussels, Belgium; Natural History Museum of Denmark, Copenhagen, Denmark; Naturalis Biodiversity Center, Leiden, the Netherlands; Museo Nacional de Ciencias Naturales-CSIC, Madrid, Spain; Real Jardín Botánico de Madrid CSIC, Spain; Zoological Research Museum Alexander Koenig, Bonn, Germany; National Museum, Prague, Czech Republic. 